\title{
Social connectedness as a determinant of mental health: A scoping review
}

2 Priya J. Wickramaratne ${ }^{1,2}$, Tenzin Yangchen ${ }^{2}$, Lauren Lepow ${ }^{3}$, Braja G. Patra ${ }^{4}$, Benjamin Glicksburg ${ }^{3}$, Ardesheer

3 Talati $^{1,2}$, Prakash Adekkanattu ${ }^{5}$, Euijung Ryu ${ }^{6}$, Joanna M. Biernacka ${ }^{6}$, Alexander Charney ${ }^{3}$, J. John Mann ${ }^{7}$,

4 Jyotishman Pathak ${ }^{4}$, Mark Olfson ${ }^{1}$, Myrna M. Weissman ${ }^{1,2}$

$5 \quad \quad{ }^{1}$ Department of Psychiatry, Vagelos College of Physicians and Surgeons, Columbia University Irving Medical

6 Center, New York, NY, United States of America

$7 \quad{ }^{2}$ Division of Translational Epidemiology, New York State Psychiatric Institute, New York, NY, United States of

8 America

$9 \quad{ }^{3}$ Departments of Psychiatry and Genetics \& Genomic Sciences, Icahn School of Medicine at Mount Sinai, New

10 York, NY, United States of America

$11{ }^{4}$ Division of Health Informatics, Department of Population Health Sciences, Weill Cornell Medicine, New York,

12 NY, United States of America

$13{ }^{5}$ Department of Information Technologies and Services, Weill Cornell Medicine, New York, NY, USA

$14{ }^{6}$ Department of Health Sciences Research, Mayo Clinic, Rochester, MN, United States of America

$15{ }^{7}$ Division of Molecular Imaging and the Neuropathology, New York State Psychiatric Institute, Departments of

16 Psychiatry and Radiology, Vagelos College of Physicians and Surgeons, Columbia University Irving Medical

17 Center, New York, NY, United States of America

*Corresponding Author 


\section{Abstract}

27 Public health and epidemiologic research have established that social connectedness promotes overall health. Yet

28 there have been no recent reviews of findings from research examining social connectedness as a determinant of

29 mental health. The goal of this review was to evaluate recent longitudinal research probing the effects of social

30 connectedness on depression and anxiety symptoms and diagnoses in the general population. A scoping review was

31 performed of PubMed and PsychInfo databases from January 2015 to December 2020 following PRISMA-ScR

32 guidelines using a defined search strategy. The search yielded 56 articles representing 52 unique studies. In research

33 with other than pregnant women, 84\% (16 of 19) studies reported that social support benefited symptoms of

34 depression with the remaining 16\% (3 of 19) reporting minimal or no evidence that lower levels of social support

35 predict depression at follow-up. In research with pregnant women, 80\% (21 of 26 studies) found that low social

36 support increased postpartum depressive symptoms. Among 3 of 4 studies that focused on loneliness, feeling lonely

37 at baseline was related to adverse outcomes at follow-up including higher risks of major depressive disorder,

38 depressive symptom severity, generalized anxiety disorder, and lower levels of physical activity. In 5 of 7 reports,

39 smaller social network size predicted depressive symptoms or disorder at follow-up. In summary, most recent

40 relevant longitudinal studies have demonstrated that social support protects adults in the general population from

41 depressive symptoms and disorders. The results, which were largely consistent across settings, exposure measures,

42 and populations, support efforts to improve clinical detection of high-risk patients, including adults with low social

43 support and elevated loneliness. 
medRxiv preprint doi: https://doi.org/10.1101/2022.01.26.22269896; this version posted January 28, 2022. The copyright holder for this preprint (which was not certified by peer review) is the author/funder, who has granted medRxiv a license to display the preprint in perpetuity.

It is made available under a CC-BY-ND 4.0 International license .

\section{Introduction}

53 While there is no universally accepted definition of social connectedness, it generally denotes a combination of

54 interrelated constructs spanning social support, social networks, and absence of perceived social isolation. There is a

55 broad-based agreement in the public health and epidemiologic literature that social connectedness protects and

56 promotes mental and physical health and decreases all-cause mortality [1-3]. Researchers in fields ranging from

57 psychology and epidemiology to sociology have been aware of these findings for several decades, but its

58 implications have only recently begun to be appreciated more widely [4]. A recent study that reviewed the

59 associations between social determinants of health and mental health outcomes [5], did not include social

60 connectedness as a social determinant of mental health.

61 In a recent study of 100,000 participants in the UK Biobank [6], frequency of confiding in others and visits with

62 family and friends emerged from over 100 modifiable risk factors as the strongest predictor of depression. This

63 suggests that social connections may have protective effects or may be modified by development of a mood

64 disorder. There is now a social connection domain in the Epic Social Determinants of Health wheel included in

65 Electronic Health Records used in many major health organizations.

66 In light of these developments, we decided to conduct a scoping review of the relevant literature published between

672015 and 2020 to evaluate the extent to which social connection influences risk for depression and anxiety. We also

68 sought to determine which aspects of social connections are most protective. Our review synthesizes recent literature

69 on the various categories of social connection (social networks, perceived emotional support, and perceived social

70 isolation) and their differential effects on depression and anxiety in specific populations. Because depression and

71 anxiety can have adverse effects on social connections [7], we restricted our search to longitudinal/cohort studies

72 from which appropriate temporal ordering that is necessary, although not sufficient, for causal inferences, can be

73 established. We performed a scoping review of the literature published during the last five years addressing whether

74 social connectedness is longitudinally associated with common mental health outcomes of depression and anxiety

75 among adults.

\section{Methods}


medRxiv preprint doi: https://doi.org/10.1101/2022.01.26.22269896; this version posted January 28, 2022. The copyright holder for this preprint (which was not certified by peer review) is the author/funder, who has granted medRxiv a license to display the preprint in perpetuity.

It is made available under a CC-BY-ND 4.0 International license .

77 Searches of PubMed and PsychInfo databases and inspection of reference lists of relevant papers published during

78 January 2015 and December 2020 were conducted following the Preferred Reporting Items for Systematic Reviews

79 and Meta-Analyses Extension for Scoping Review (PRISMA-ScR) guidelines. The databases were searched using

80 the following search strategy: ((("social* support *"or "social* isolation*" or "social* network*") AND (Depression

81 OR Anxiety)) AND (("2015/1/1"[Date - Publication]: "2020/12/31"[Date - Publication]))) AND (English

82 [Language]). Figure 1 presents a flow diagram displaying the process of searching and selecting the studies.

\section{Search strategy and selection criteria}

84 For inclusion in the review, studies were required to meet the following criteria: (a) employed longitudinal/cohort

85 study design; (b) published in peer-reviewed journals between the years 2015 and 2020 in English; (c) assessed

86 social support, social networks, or social isolation as one of the main predictor variables; (d) the mental health

87 outcomes analyzed in the articles had to be either depression or anxiety; and (e) recruited participants aged 18 years

88 or older in the study.

89 Studies were excluded if: (a) the article did not report original data (e.g., the article was a theoretical paper, review

90 paper, or meta-analysis); (b) social connectedness as operationalized in the review was not measured as a predictor

91 variable; (c) the sample included participants with pre-existing health conditions (e.g., HIV, chronic disease, cancer,

92 stroke, etc.) except mental health conditions that are generally comorbid with depression or anxiety; and (d) the

93 study did not focus on adults.

\section{Data Extraction}

95 After removing irrelevant titles and duplicates, the remaining articles were reviewed with respect to the eligibility

96 criteria. Two authors (TY and PW) scrutinized titles and abstracts, and full text articles potentially eligible for this

97 review were obtained. Key information from included papers was initially extracted and tabulated by one author

98 (TY). The accuracy of this information was independently verified by another co-author (PW). Discrepancies were

99 resolved through consensus. The data extracted included basic descriptive information about the sample, study type,

100 length of follow-up, relevant predictor and outcome measures, and main findings. In cases where the same parent

101 study data were employed in more than one publication, the papers were considered one study. Due to the wide 
medRxiv preprint doi: https://doi.org/10.1101/2022.01.26.22269896; this version posted January 28, 2022. The copyright holder for this preprint (which was not certified by peer review) is the author/funder, who has granted medRxiv a license to display the preprint in perpetuity.

It is made available under a CC-BY-ND 4.0 International license .

102 variation in study designs and populations, we did not attempt meta-analysis, but rather provide a narrative synthesis

103 of the main findings.

\section{Results}

105 The initial search yielded 15,497 articles, and 6,532 articles were retained after duplicates and irrelevant articles

106 were removed. After title and abstract screening, 105 articles were assessed for eligibility. Among studies selected

107 for full-text review, 45 articles were deemed ineligible and excluded for various reasons: 10 did not employ

108 longitudinal study design, 6 recruited participants aged younger than 18 years, 11 did not assess social support,

109 social networks, and/or social isolation as predictor variable, 16 did not have depression or anxiety as the main

110 outcome variable, and 2 were not from peer-reviewed sources. The PRISMA flowchart (Fig. 1) provides further

111 detail on reasons for exclusion. Therefore, a total of 56 articles representing 52 unique studies met inclusion criteria

112 for this scoping review.

\section{Study Characteristics}

\section{Social Support}

115 A little over half of the recent articles on the effect of social support on depression addressed the issues of

116 depression in pregnant women, while the rest addressed the association of social support with anxiety or depression,

117 in a variety of populations, other than pregnant women. We begin our review with nonpregnant populations because

118 the results are of broader general relevance.

\section{Study Samples other than pregnant women}

120 Table 1a lists the 20 articles that reported quantitatively on the longitudinal effects of social support on depression or

121 anxiety in samples other than pregnant women, but two papers reported on one study, resulting in a total of 19

122 studies. The sample size of the included studies ranged between 86 and 7171 participants. Majority of the studies

123 were conducted in North America (8 studies), and the remaining were from Europe (6 studies), Asia (2 studies), and

124 Australia (2 studies). One study was international in scope and sampled students from 76 host countries. All studies

125 followed up the cohorts for at least one to two years and eight for over two years. 
medRxiv preprint doi: https://doi.org/10.1101/2022.01.26.22269896; this version posted January 28, 2022. The copyright holder for this preprint (which was not certified by peer review) is the author/funder, who has granted medRxiv a license to display the preprint in perpetuity.

It is made available under a CC-BY-ND 4.0 International license .

127 The nineteen included studies used a threshold score on a depression rating scale to measure depressive symptoms, 128 and the Center for Epidemiological Studies Depression Scale was the most frequently utilized scale, being used in 129 six of the studies. Other measures with established psychometric properties included in this Table were as follows:

130 Patient Health Questionnaire-9, Geriatric Depression Scale, Inventory of Depressive Symptomatology, Symptom

131 Checklist Core Depression Scale, and Brief Symptom Inventory. In order to assess anxiety and depressive

132 symptoms, three studies [8,9,10] used the Hospital Anxiety and Depression Scale, and two [11,12] used Depression

133 Anxiety Stress Scale. Additionally, one study $[13,14]$ used Composite International Diagnostic Interview (CIDI), a 134 structured diagnostic interview to measure the presence of a major depressive disorder (MDD) according to DSM-

135 IV criteria. The social support measures in these studies varied considerably, with five studies $[10,12,15-17]$ using

136 the original or the adapted version of the Multidimensional Scale of Perceived Social Support (MSPSS). Two

137 studies [8,18] employed Demand-Control-Support-Questionnaire (DCSQ) to assess workplace social support, and

138 three studies $[9,19,20]$ used Social Provision Scale (SPS). A scale in the Deployment Risk and Resilience Inventory

139 (DRRI) was employed in one veteran study to assess the extent to which they perceive assistance and

140 encouragement in the war zone from fellow unit members [11]. Four studies [21-24] used questionnaires that were

141 developed by the authors. The Interview Schedule for Social Interaction — availability of Attachment Scale was used

142 to measure the perceived availability of interpersonal support [25]. Whitley et al [26] used the Family Support Scale

143 (FSS), and Haverfield et al. [27] used a subscale of the Basic Need Satisfaction Scale to assess general social

144 support (Table 1a).

\section{Effects on Depression/Anxiety}

146 Social support has been shown benefit in abating symptoms of depression over time in $16 / 19$ or $84 \%$ of the studies

147 (Table 1a). Analyses of mental health conditions in a sample of nationally dispersed war-zone veterans for over

148 seven years indicated that higher levels of social support post-deployment were associated with decreased risk of

149 depression and anxiety disorders, as well as less severe symptoms [11]. Moreover, reduced levels of perceived

150 support at the workplace were associated with increased levels of depression symptoms [18], which aligns with

151 previous research that showed a direct influence of social support on the well-being of medical staff workers in the

152 subsequent study waves [8]. A five-year study of rural community residents also found that low perceived 
153 interpersonal support was associated with adverse mental health outcomes, including depression [25]. Billedo et al.

154 [19] found short-term reciprocal associations between social support and depressive symptoms in sojourning

155 students. They further stated that face-to-face interaction with the host-country network had immediate positive

156 effects on perceived social support, which subsequently predicted lower depressive symptoms [19]. Even in samples

157 of emerging adults, higher levels of perceived social support were protective against depressive and anxiety

158 symptoms [20,21]. Boyden and colleagues followed a sample of parents of critically ill children over two years and

159 found that greater perceived social support was associated with lower anxiety levels across assessments [9]. Higher

160 baseline social support remained negatively associated with lower parental anxiety scores at 12 months $(\mathrm{B}=-0.12$,

$161 p=0.03 ; 95 \% \mathrm{CI}=-.23$ to -.01$)$ and 24 months $(\mathrm{B}=-0.11, p=0.04 ; 95 \% \mathrm{CI}=-0.21$ to -0.01$)$. This inverse association

162 had dissipated by 24 months in their adjusted modeling [9]. Their findings concur with other aforementioned studies

163 that demonstrated a benefit of having supportive relationships.

164 Interestingly, in terms of the source of social support, the role of family support remains unclear. One study of

165 married Arab immigrant women in the U.S. did not find family support to be protective against depression. Instead,

166 support from friends was found predictive of fewer depressive symptoms at follow-up [15]. However, the results of

167 this study contrast with those of Zhou et al., [17] who showed that more perceived family support decreased usage

168 of social networking sites, which was followed by decreased depressive symptoms among Chinese college students.

169 Similarly, Haverfield et al. [27], analyzed data from patients with co-occurring disorders at treatment intake and

170 across follow-ups in the United States and found that deficits in family support were the most consistent predictor of

171 greater depression and substance use severity [27]. Consistent with previous studies on social support drawn from

172 family and their positive impacts, two studies $[16,26]$ specifically focused on custodial grandparents in the U.S.

173 showed that while elevated caregiving stress may negatively affect grandparent caregivers' mental and overall

174 health over time, greater social support from family networks may reduce depression accompanying caregiving.

175 According to Whitley et al., [26] social support has a mediating effect on the relationship between depression and

176 mental health quality of life in older (55+) African American custodial grandmothers, but not in their younger $(\leq 55)$

177 counterparts.

178 Although depression peaks in young adulthood, it either can persist or emerge later in life, as evidenced by the three

179 studies focusing exclusively on the role of social support in samples of adults aged 55 and older. Misawa and Kondo 
180 (2019), in a study of 3464 Japanese older people, reported that social support was unrelated to changes in depressive

181 symptoms but added that social factors of having hobbies and meeting frequently with friends were associated with

182 improved late-life depression. This link between social interaction and social support was only observed to be

183 protective for men [23]. Conversely, another study spanning eight years of follow-up of older adults in England

184 found a bidirectional association between depressive symptoms and spousal support [24]. The authors found an

185 average decrease in positive support (or an increase in negative support) over time in age- and gender-adjusted

186 models, which later predicted increasing depressive symptom trajectory [24] Another study on older people with

187 depression revealed that a chronic course of depression might decrease received social support over time [22].

188 Moreover, their findings suggest that pre-existing depression in concert with less social support may predispose

189 older persons, especially men and single people, to more depression over time [22].

190 A few studies $(3 / 19=16 \%)$ found minimal or no evidence that lower levels of social support predict depression at

191 follow-up. For example, in a naturalistic cohort study of Noteboom et al. [13] people with a prior history of

192 depression reported a smaller network size and less emotional support at baseline However, these structural

193 (network size or having a partner) and the perceived aspects of social support had no predictive value in the

194 longitudinal data. Similarly, only negative experiences with social support proved to be a risk factor for non-

195 remission, independent of other social-relational variables in depressed persons [14]. Steine et al. [10]

196 found statistically significant weak reciprocal associations between perceived social support and depression and

197 anxiety symptoms over time among adult survivors of childhood sexual abuse. Although, Porter and Chambless

198 reported a link between higher odds of relationship dissolution and social anxiety, they observed no differences

199 between participants with high versus low social anxiety with regard to the amount of social support provided by

200 their partners [12].

\section{Social support for women during and post pregnancy}

202 Table $1 \mathrm{~b}$ presents results from twenty-eight articles examining associations between social support and depression

203 during pregnancy or postpartum, uniquely vulnerable periods for women during which they may experience a range

204 of psychosocial stressors. Two pairs of papers provided findings based on identical samples and were reported in a

205 combined table entry, resulting in twenty-six studies. Studies were predominantly conducted in Asia (42\%) and

206 North America (31\%), with the remaining studies from Europe (15\%), South America (4\%), Africa (4\%), and 
207 Australia (4\%). In terms of individual countries, four studies were conducted in the United States, followed by

208 Canada, China, Japan, and Turkey, all with three studies each. Sample sizes varied from 54 participants in a follow-

209 up of a previous randomized trial [28] to 12,386 couples in a study with findings on both maternal and paternal

210 depression [29]. Most of the included studies [28,30-43] began in the mid or late pregnancy, three [44-46] started in

211 early pregnancy, and eight studies [29,47-53] started after birth. Women were on average aged between 18 and 40

212 years old. The most commonly used measures of social support and depression were, respectively, the Medical

213 Outcomes Study Social Support Survey (MOS-SSS) and the Edinburgh Postnatal Depression Scale (EPDS) (Table

$2141 b)$

215 The majority of the studies $(21 / 26=80 \%)$ found low social support increased postpartum depressive symptoms.

216 Women with higher perceived social support exhibited lower depression $(b=-0.308, \mathrm{SE}=0.036, \mathrm{p}<.001)$ and

217 anxiety $(b=-0.225, \mathrm{SE}=0.039, p<.001)$ symptom severity across the peripartum period [31]. Similar results were

218 obtained by other studies $[28,38,43,44,48]$ conducted to investigate the trajectory of the association between

219 depression and perceived social support. A study in Taiwan comprising 407 immigrant and native-born women

220 showed that a presence of depression symptoms during pregnancy $(\beta=0.246 ; p<0.001)$ and deficient social support

$221 \quad(\beta=-0.233 ; \mathrm{p}<0.001)$ positively covaried with depressive symptoms at 3- months postpartum [34]. The significant

222 protective factor of social support against postpartum depression was also highlighted in another study through a

223 mediating effect of good clinical delivery. ${ }^{46}$ Moreover, insufficient social support and frequent quarrels during

224 pregnancy were associated with significant increase in joint postpartum depressive symptoms in mothers and fathers

225 [29]. Tani et al. demonstrated a protective role of maternal and paternal relationships on postpartum depression in

226 nulliparous women [42].

227 Asselmann and colleagues [32] found a bidirectional relationship between peripartum social support and

228 psychopathology. They concluded that low social support increased the risk for anxiety and depressive disorders,

229 and these disorders before pregnancy, in turn, fostered dysfunctional relationships and lowered social support across

230 the peripartum period [32]. Women with comorbid anxiety and depression were at higher risk for lacking social

231 support during this timeframe [32]. Social support appeared to be a predictor of depression from mid-pregnancy to

232 six months postpartum, particularly in late pregnancy. Nonetheless, the predictive effect of social support on anxiety

233 was only observed in late pregnancy [43]. Latina women who had lower social support during the third trimester of 
234 pregnancy were reported to be at greater risk of depressive symptoms at six months in the postpartum, which was

235 consistent with a study on primiparous mothers [49]. Specifically, we found that women with lower social support

236 and higher self-reported adherence to the Traditional Female Role were at the highest risk of experiencing

237 postpartum depressive symptoms [30].

238 Data from Canada reported inverse associations between 1) social support during pregnancy and anxiety and

239 depression postnatally (RR $1.50,95 \%$ CI 1.24 to 1.82 ) and 2) social support at four months postpartum and one year

240 postpartum (RR 1.65, 95\% CI 1.31 to 2.09) [48]. In contrast to these studies, Schwab-Reese et al. stated that social

241 support was not protective against depressive or anxiety symptoms at six months postpartum as it was at three

242 months postpartum [50].

243 Satisfaction with all the types of support (emotional, material, esteem, and informative) from the spouse reduced the

244 psychological disorders in mothers as much in the prenatal compared to the postpartum period [40]. Among

245 immigrant mothers in Taiwan from China or Vietnam, emotional support was found to be significantly and inversely

246 associated with postpartum depression [34]. Emotional and informational support were identified as the most

247 important types of social support for postpartum anxiety [48]. Marginal structural models were employed to evaluate

248 the time-varying associations of low social support (before and in early pregnancy) with depression in late

249 pregnancy in a cohort of Peruvian women, and analyses suggested that women with sustained low scores on the 6-

250 item Sarason Social Support Questionnaire (SSQ-6) were at higher risk of antepartum depression [43]. The authors

251 also found a stronger association of fewer persons providing social support on depression risk than low social

252 support satisfaction.

253 Others have found that not all forms of social support during a woman's transition into motherhood are equally

254 beneficial in alleviating depression and anxiety symptoms. Razurel et al. reported that support provided by one's

255 partner buffered the effects of stress on depression, although support from friends or professionals did not [39].

256 Although social support from family and friends was deemed less prominent than that from the spouse, studies

$257[35,40]$ showed that these sources of support also had an influence on maternal mental health. A study evaluating the

258 impact of family relationships and support on perinatal depressive symptoms between the third trimester of

259 pregnancy and two to six months postpartum noted that the incidence and persistence of depression symptoms were

260 predicted by lower baseline perceived emotional support from the mother-in-law and the husband, respectively [33]. 
medRxiv preprint doi: https://doi.org/10.1101/2022.01.26.22269896; this version posted January 28, 2022. The copyright holder for this preprint (which was not certified by peer review) is the author/funder, who has granted medRxiv a license to display the preprint in perpetuity.

It is made available under a CC-BY-ND 4.0 International license .

261 In a large population-based study, increases in partner and family support had a more protective effect against

262 anxiety and stress, and higher than average levels of anxiety and stress led to maternal-reported decreases in support

263 [54].

264 Some studies [37,52] did not find associations between low perceived social support during pregnancy and

265 postpartum depression. Ohara et al. [46] showed that satisfaction with social support did not directly predict

266 depression in the postpartum period at a statistically significant level. Further, their path model revealed that less

267 satisfaction with the social support received during pregnancy was rather a cause of postpartum depression. This

268 indirect link of social support with depression in the postpartum period is in line with another study with slightly

269 larger sample size, one year later, by the same first author [45]. While one study [55] found that the number of

270 supportive persons during pregnancy had a more substantial effect on decreasing postpartum depressive symptoms

271 in depressed relative to non-depressed mothers, their analyses also showed that satisfaction with social support was

272 not a significant predictor of postpartum depression. The inconsistent findings on social support and depression and

273 anxiety across included studies can be partially attributed to varying operational definitions of social support,

274 utilization of different self-report social support and depression measures, and insufficient control for confounding

275 variables.

276 Social isolation/Loneliness

277 Given that both these concepts were concurrently assessed in addressing mental health outcomes in some studies,

278 articles that met the inclusion criteria of the current review and examined the subjective counterpart of social

279 isolation were included in Table 2. This table presents characteristics of selected studies that explored the impact of

280 social isolation on depression and anxiety disorders. The four studies [56-59] reported on a total of 7,820 older

281 adults aged 50 and above in European countries, namely Ireland, Wales, Germany, and the Netherlands. The number

282 of participants in the studies varied considerably, from 285 participants with a primary diagnosis of depression in a

283 two-year follow-up study to 5,066 in a report on a well-characterized cohort of adults from Ireland [56]. Social

284 isolation and loneliness (perceived social isolation) are intricately related, albeit conceptually distinct.

285 Domènech-Abella and colleagues (2019) found social isolation and loneliness to be antecedent risk factors for

286 incident depression or exacerbating late-life generalized anxiety or major depressive disorder independently [56].

287 The authors cautioned readers not to underestimate the subjective aspects of social isolation. Their findings are 
concordant with a previous study by Holvast et al. [59] which showed that loneliness was independently associated

with more severe depressive symptoms at follow-up $(\beta=0.61 ; 95 \%$ CI $0.12-1.11)$. Moreover, participants who

290 scored high on the subjective appraisal of social isolation, measured by six-item de Jong Gierveld Loneliness Scale

291 with subscales for emotional loneliness (perceived absence of intimate relationships) and social loneliness

292 (perceived lack of a wider circle of friends and acquaintances), at baseline had a lower likelihood of achieving

293 remission two years later [59]. The Composite International Diagnostic Interview (CIDI) was employed in both

294 studies to measure depressive disorders at baseline [56,59], and Inventory of Depressive Symptoms (IDS) was used

295 to assess the depression course at the follow-up in one study [59].

296 Two studies [57,58] utilized the Lubben Social Network Scale, a validated instrument designed to gauge social

297 isolation in the elderly. Analysis of Cognitive Function and Ageing Study-Wales (CFAS-Wales) by Evans et al.

298 (2019) showed that people with depression or anxiety experience poorer social relationships and higher social

299 isolation and loneliness relative to those without such symptomatology, despite reporting an equivalent level of

300 social contact [57]. The apparent reductions in negative affect at follow-up in over half of the respondents with

301 clinically relevant depression or anxiety, diagnosed using the Automated Geriatric Examination for Computer-

302 Assisted Taxonomy (AGECAT) algorithm, at baseline could be due to biopsychosocial changes intrinsic to ageing

303 and/or cohort effects. Results by Herbolsheimer et al. (2018) opposed previous findings, stating that social isolation

304 from friends and neighbors at the baseline was not directly associated with depressive symptoms at the 3-year

305 follow-up [58]. Of importance, the authors also showed that being socially isolated from friends and neighbors was

306 related to lower levels of out-of-home physical activity, which predicted more depressive symptoms after three years

$307 \quad(\beta=.014,95 \%$ CI .002 to .039) [58]. These reported findings demonstrate the potentially detrimental effect of

308 objective and subjective social isolation on mood disorders in later life. Extant evidence suggests the importance of

309 considering both social isolation and loneliness without the exclusion of the other in efforts to mitigate risk.

\section{$310 \quad$ Social networks}

311 Five studies, i.e., seven papers, were identified that examined the longitudinal relationship between social networks

312 and depression or anxiety (see Table 3). Four [56,60-63] of the five studies [13,14,56,60-63] on social networks

313 focused on older adults. Community-dwelling individuals aged 75 and older with restricted social networks were

314 more likely to develop depression compared to those who maintained an integrated social network [61]. While it has 
315 also been noted that respondents who experienced social loss within the last six months reported a higher risk of

316 depression in old age, the adverse effects of loss on depression could be attenuated by the existence of an integrated

317 social network [61]. In a large follow-up study spanning ten years that recruited older female nurses, lower social

318 networks increased the risk of incident late-life depression in age-adjusted models [60]. In line with these results,

319 another study on the elderly showed that a smaller network size measured using the Berkman-Syme Social Network

320 Index is a robust risk factor of major depression and generalized anxiety disorder [56]. Conversely, one study on

321 American adults aged 57-85 years denies this relationship as no direct effects of social networks on frequencies of

322 depression symptoms were detected at follow-up [63]. It is worth noting that the same study also showed that social

323 networks predicted higher levels of perceived isolation $(\beta=0 \cdot 09 ; p<0 \cdot 0001)$, which in turn predicted higher levels of

324 depression and anxiety symptoms $(\beta=0 \cdot 12 ; p<0 \cdot 0001)[63]$. According to papers $[13,14]$ that used data from

325 NESDA and NESDO, the size of social networks at baseline did not predict depression at follow-up. For adults with

326 a pre-existing diagnosis of major depressive disorder, only the social network characteristic of living in a larger

327 household was reported to have a unique predictive value for depression course [14].

328 While smaller social networks emerged as a predictor of depression in three of the five studies, the remaining studies

329 showed no predictive value of social networks in the depression course $(2 / 5=40 \%)$. The extent to which measures

330 assessed the concept of social networks across the included studies could be disputed and may account for between-

331 study inconsistencies. Some assessed using a count of the number of people in the social network [13,14], one

332 assessed social network type (restricted vs. integrated) [61], four assessed network size and frequency of interaction

333 with network members [56,60,62,63], and one study assessed additional indicators such as three layers of human

334 relationships (community-layer, interpersonal-layer, and partner-layer connection) [62]. These longitudinal studies

335 found that social networks have both direct and buffering effects on psychological wellbeing.

\section{Discussion}

337 The goal of this scoping review was to determine current knowledge regarding the effect of social connection on 338 depression and/or anxiety symptoms and diagnoses in the general population. Lund et al. (2018) noted that while 339 there is no universal definition of social connection, it is considered an umbrella term that generally includes the 340 following components: social support, social networks, social isolation and loneliness [64]. 
341 Much of the research investigating the role of social connections in the studies published in the last five years has

342 focused primarily on social support as compared to the other components of social connection and, more

343 specifically, on perceived emotional support. The majority of studies, regardless of whether the support was

344 received or perceived, showed that, in general, social support was a protective factor for both depressive symptoms

345 and disorders. The consistency of the findings across a variety of settings, measures of exposure, and populations

346 supports the generalizability of the findings in this review. The measures used varied in the type of social support

347 assessed, although most studies assessed subjective and objective emotional support rather than structural support.

348 Few of the studies examined the effect of social support on anxiety symptoms or diagnoses, and those that did

349 investigate these associations found the results mixed and weak. A single study examined the effect of social support

350 on social anxiety and found no association [12]. However, there were too few studies to draw any firm conclusions.

351 Over half of these studies investigated the effects of social support on depression/ anxiety at various stages of

352 pregnancy. The preponderance of studies that investigated the effect of social support on pre/postpartum depression

353 could be due to our restriction of included studies in this review to longitudinal studies since the effects of social

354 support during pregnancy on postpartum depression can readily be assessed by employing longitudinal study design.

355 There were far fewer studies that examined the longitudinal relationship between social networks and anxiety or

356 depression, the majority of which focused on older adults. Although measures which assessed the concept of social

357 networks were somewhat inconsistent and may have led to mixed results between studies, on the whole, social

358 networks have direct and buffering effects on depression /anxiety. More studies of the effects of social networks

359 such as size and structure and the characteristics of network ties, frequency of contact, reciprocity, duration, and

360 intimacy will give us a greater understanding by which these networks impact depression and anxiety, and

361 opportunities for intervention.

362 A small number of studies met our inclusion criteria for exploring the impact of social isolation on depression and

363 anxiety. Despite some methodological limitations of these studies, there was fairly strong evidence that both social

364 isolation and loneliness (perceived social isolation) were potentially detrimental in terms of development of mood

365 disorders in later life. 
The extant literature recommends that the effects of the individual components rather than a composite measure of social connection be used because the correlation between these components is relatively low. Investigating the effects of individual components could lead to greater insight into possible causal pathways and appropriate interventions. Epidemiological research has generally focused on the structural (e.g., social network size /density, marital status, living arrangements) or functional aspects of social relationships (received and perceived social

371 support, perceived social isolation), while some researchers have also studied multi-dimensional approaches, i.e., a

372 combination of structural and functional aspects. On the rare occasions where researchers have attempted to

373 combine the effects of the components of social connection on the diagnostic outcomes, two different approaches

374 have been used: 1. They have either used multivariable regression models (linear or logistic - depending on the 375 outcome) with each of the components included as a separate predictor [34]. They have treated "social connection"

376 as an underlying latent variable, while treating the individual components as the observed or "manifest" variables

$377[65]$.

378 Inferences from this review should be drawn cautiously, considering some limitations. Firstly, we only included 379 studies published in the English language. Other papers may be available in different languages. Secondly, we 380 conducted a scoping review and not a systematic review; thus, the included papers were not assessed based on their 381 quality. Some of the included studies in this review have small sample size. These studies must be replicated in 382 larger, heterogeneous populations with a longer interval between the baseline assessment of social connectedness

383 measures and follow-up of depressive and anxiety symptoms to ensure reliable and valid results for inferring the

384 direction of causality. Despite these limitations, the longitudinal/prospective research reviewed here provides current 385 knowledge on the effects of social connection on depression and anxiety and sheds important insights into possible 386 causal mechanisms and a deeper understanding of how prior social circumstances can affect later mental health 387 outcomes.

\section{Clinical and Policy Implications}

389 The results of this scoping review have implications for clinical practice. Strong associations between lacking social 390 connections and risk of depression underscore the importance of improving clinical detection of high-risk patients, 391 including those with low received or perceived social support and elevated perceived loneliness. Because these 392 characteristics may be difficult for primary care physicians to detect in their patients [66], consideration might be 
393 given to implementing brief screening instruments analogous to clinical tools that have been recommended to assess

394 network size [67]. The link between social connections and improved adherence to medical recommendations [68]

395 may motivate practitioners to detect and seek to address social isolation in their patients. However, meaningful

396 clinical progress in addressing a lack of social connections may depend upon readily accessible and effective

397 interventions.

398 The results also have implications for social policy. Because the prevalence of loneliness increases [69] and the size

399 of social networks declines [70] as older adults age, the present findings bolster the public health rationale for

400 addressing social vulnerabilities among older adults. Although some aspects of loneliness and social isolation likely

401 involve genetic susceptibility [71], other aspects appear to involve characteristics of the neighborhood environment

402 [72]. Policymakers seeking to reduce the adverse mental health effects of social isolation among older adults, for

403 example, might weigh the benefits of designing supportive housing structures and neighborhoods for older adults

404 that provide greater opportunities for socialization and formation of social connections.

\section{$405 \quad$ Figure Legend}

406 Fig. 1. PRISMA flow chart of the scoping review 
medRxiv preprint doi: https://doi.org/10.1101/2022.01.26.22269896; this version posted January 28, 2022. The copyright holder for this preprint (which was not certified by peer review) is the author/funder, who has granted medRxiv a license to display the preprint in perpetuity.

It is made available under a CC-BY-ND 4.0 International license .

\section{References}

418 1. Becofsky KM, Shook RP, Sui X, Wilcox S, Lavie CJ, Blair SN. Influence of the source of social support and 419 size of social network on all-cause mortality. Mayo Clin Proc. 2015;90(7):895-902.

420 2. Lamblin M, Murawski C, Whittle S, Fornito A. Social connectedness, mental health and the adolescent brain. $421 \quad$ Neurosci Biobehav Rev. 2017;80:57-68.

422 3. Ashida S, Heaney CA. Differential associations of social support and social connectedness with structural features of social networks and the health status of older adults. Journal of Aging and Health. 2008;20(7):872-93.

4. Holt-Lunstad J, Robles TF, Sbarra DA. Advancing social connection as a public health priority in the United States. Am Psychol. 2017;72(6):517-530.

5. Choi KW, Stein MB, Nishimi KM, Ge T, Coleman JRI, Chen CY, et al. An exposure-wide and mendelian randomization approach to identifying modifiable factors for the prevention of depression. Am J Psychiatry. 2020;177(10):944-954.

6. Silva M, Loureiro A, Cardoso G. Social determinants of mental health: A review of the evidence. The European Journal of Psychiatry. 2016;(4):259-92.

7. Ojagbemi A, Bello T, Gureje O. The roles of depression and social relationships in the onset and course of loneliness amongst Nigerian elders. Int J Geriatr Psychiatry. 2021;36(4):547-557.

8. Berthelsen M, Pallesen S, Magerøy N, Tyssen R, Bjorvatn B, Moen BE, et al. Effects of psychological and social factors in shiftwork on symptoms of anxiety and depression in nurses: A 1-year follow-up. Journal of Occupational and Environmental Medicine. 2015;57(10):1127-37.

9. Boyden JY, Hill DL, Carroll KW, Morrison WE, Miller VA, Feudtner C. The association of perceived social support with anxiety over time in parents of children with serious illnesses. Journal of Palliative Medicine. $2020 ; 23(4): 527-34$. childhood sexual abuse. Child Abuse \& Neglect. 2020;107:104566. 
11. Ciarleglio MM, Aslan M, Proctor SP, Concato J, Ko J, Kaiser AP, et al. Associations of stress exposures and social support with long-term mental health outcomes among US Iraq War Veterans. Behavior Therapy. 2018;49(5):653-67.

12. Porter E, Chambless DL. Social anxiety and social support in romantic relationships. Behavior Therapy. 2017;48(3):335-48.

13. Noteboom A, Beekman AT, Vogelzangs N, Penninx BW. Personality and social support as predictors of first and recurrent episodes of depression. Journal of Affective Disorders. 2016;190:156-61.

14. Van Den Brink RH, Schutter N, Hanssen DJ, Elzinga BM, Rabeling-Keus IM, Stek ML, et al. Prognostic

15. Aroian K, Uddin N, Blbas H. Longitudinal study of stress, social support, and depression in married Arab immigrant women. Health Care for Women International. 2017;38(2):100-17.

16. Hayslip Jr B, Blumenthal H, Garner A. Social support and grandparent caregiver health: One-year longitudinal findings for grandparents raising their grandchildren. Journals of Gerontology Series B: Psychological Sciences and Social Sciences. 2015;70(5):804-12.

17. Zhou M, Li F, Wang Y, Chen S, Wang K. Compensatory social networking site use, family support, and

19. Billedo CJ, Kerkhof P, Finkenauer C, Ganzeboom H. Facebook and face-to-face: Examining the short-and long-term reciprocal effects of interactions, perceived social support, and depression among international students. Journal of Computer-Mediated Communication. 2019;24(2):73-89. 
21. Crowe L, Butterworth P. The role of financial hardship, mastery and social support in the association between employment status and depression: Results from an Australian longitudinal cohort study. BMJ Open. 2016;6(5):e009834. depression in older people related to received support over time? Results from a longitudinal populationbased study. International Journal of Geriatric Psychiatry. 2017;32(6):657-63.

23. Misawa J, Kondo K. Social factors relating to depression among older people in Japan: analysis of longitudinal panel data from the AGES project. Aging \& Mental Health. 2019;23(10):1423-32.

24. Stafford M, Antonucci TC, Zaninotto P. Joint trajectories of spousal social support and depressive symptoms in older age. Journal of Aging and Health. 2019;31(5):760-82.

25. Handley TE, Rich J, Lewin TJ, Kelly BJ. The predictors of depression in a longitudinal cohort of community

26. Whitley DM, Kelley SJ, Lamis DA. Depression, social support, and mental health: A longitudinal mediation analysis in African American custodial grandmothers. The International Journal of Aging and Human Development. 2016;82(2-3):166-87.

27. Haverfield MC, Ilgen M, Schmidt E, Shelley A, Timko C. Social support networks and symptom severity among patients with co-occurring mental health and substance use disorders. Community Mental Health Journal. 2019;55(5):768-76.

28. Milgrom J, Hirshler Y, Reece J, Holt C, Gemmill AW. Social support—a protective factor for depressed perinatal women? International Journal of Environmental Research and Public Health. 2019;16(8):1426. formal social support during pregnancy and joint maternal and paternal postnatal depression: Data from the French representative ELFE cohort study. International Journal of Social Psychiatry. 2020;66(5):431-41.

30. Albuja AF, Lara MA, Navarrete L, Nieto L. Social support and postpartum depression revisited: the traditional female role as moderator among Mexican women. Sex Roles. 2017;77(3-4):209-20.

31. Asselmann E, Kunas SL, Wittchen HU, Martini J. Maternal personality, social support, and changes in depressive, anxiety, and stress symptoms during pregnancy and after delivery: A prospective-longitudinal study. Plos One. 2020;15(8):e0237609. 
medRxiv preprint doi: https://doi.org/10.1101/2022.01.26.22269896; this version posted January 28, 2022. The copyright holder for this preprint

(which was not certified by peer review) is the author/funder, who has granted medRxiv a license to display the preprint in perpetuity.

It is made available under a CC-BY-ND 4.0 International license.

32. Asselmann E, Wittchen HU, Erler L, Martini J. Peripartum changes in social support among women with and without anxiety and depressive disorders prior to pregnancy: A prospective-longitudinal study. Archives of Women's Mental Health. 2016;19(6):943-52.

33. Cankorur VS, Abas M, Berksun O, Stewart R. Social support and the incidence and persistence of depression between antenatal and postnatal examinations in Turkey: A cohort study. BMJ Open. 2015;5(4):e006456.

34. Chen HH, Chien LY. A comparative study of domestic decision-making power and social support as predictors of postpartum depressive and physical symptoms between immigrant and native-born women. PloS One. 2020;15(4):e0231340.

35. Faleschini S, Millar L, Rifas-Shiman SL, Skouteris H, Hivert MF, Oken E. Women's perceived social support: associations with postpartum weight retention, health behaviors and depressive symptoms. BMC Women's Health. 2019;19(1):1-8.

36. Hare MM, Kroll-Desrosiers A, Deligiannidis KM. Peripartum depression: Does risk versus diagnostic status impact mother-infant bonding and perceived social support? Depression and Anxiety. 2020;38(4):390-99.

37. Li Y, Long Z, Cao D, Cao F. Social support and depression across the perinatal period: a longitudinal study. Journal of Clinical Nursing. 2017;26(17-18):2776-83.

38. Racine N, Zumwalt K, McDonald S, Tough S, Madigan S. Perinatal depression: The role of maternal adverse childhood experiences and social support. Journal of Affective Disorders. 2020;263:576-81. and depressive symptoms, anxiety, and parental self-efficacy in primiparous mothers and the role of social support. Women \& Health. 2017;57(2):154-72.

40. Razurel C, Kaiser B. The role of satisfaction with social support on the psychological health of primiparous mothers in the perinatal period. Women \& Health. 2015;55(2):167-86.

41. Senturk V, Abas M, Dewey M, Berksun O, Stewart R. Antenatal depressive symptoms as a predictor of deterioration in perceived social support across the perinatal period: A four-wave cohort study in Turkey.

522 42. Tani F, Castagna V. Maternal social support, quality of birth experience, and post-partum depression in primiparous women. The Journal of Maternal-Fetal \& Neonatal Medicine. 2017;30(6):689-92. 
43. Zhong QY, Gelaye B, VanderWeele TJ, Sanchez SE, Williams MA. Causal model of the association of social support with antepartum depression: A marginal structural modeling approach. Am J Epidemiol. 2018;187(9):1871-1879.

44. Gan Y, Xiong R, Song J, Xiong X, Yu F, Gao W, et al. The effect of perceived social support during early pregnancy on depressive symptoms at 6 weeks postpartum: A prospective study. BMC Psychiatry. 2019;19(1):1-8.

45. Ohara M, Nakatochi M, Okada T, Aleksic B, Nakamura Y, Shiino T, et al. Impact of perceived rearing and social support on bonding failure and depression among mothers: A longitudinal study of pregnant women. Journal of Psychiatric Research. 2018;105:71-7.

46. Ohara M, Okada T, Aleksic B, Morikawa M, Kubota C, Nakamura Y, et al. Social support helps protect against perinatal bonding failure and depression among mothers: A prospective cohort study. Scientific Reports. 2017;7(1):1-8.

47. Chen HH, Hwang FM, Lin LJ, Han KC, Lin CL, Chien LY. Depression and social support trajectories during 1 year postpartum among marriage-based immigrant mothers in Taiwan. Archives Of Psychiatric Nursing. 2016;30(3):350-5.

48. Hetherington E, McDonald S, Williamson T, Tough S. Trajectories of social support in pregnancy and early postpartum: Findings from the All Our Families cohort. Social Psychiatry and Psychiatric Epidemiology. 2020;55(2):259-67.

49. Leonard KS, Evans MB, Kjerulff KH, Downs DS. Postpartum perceived stress explains the association between perceived social support and depressive symptoms. Women's Health Issues. 2020;30(4):231-9.

50. Schwab-Reese LM, Schafer EJ, Ashida S. Associations of social support and stress with postpartum maternal mental health symptoms: Main effects, moderation, and mediation. Women \& Health. 2017;57(6):723-40.

51. Tsai AC, Tomlinson M, Comulada WS, Rotheram-Borus MJ. Food insufficiency, depression, and the modifying role of social support: Evidence from a population-based, prospective cohort of pregnant women in peri-urban South Africa. Social Science \& Medicine. 2016;151:69-77. Sci J. 2020;39(4):327-335. 
medRxiv preprint doi: https://doi.org/10.1101/2022.01.26.22269896; this version posted January 28, 2022. The copyright holder for this preprint (which was not certified by peer review) is the author/funder, who has granted medRxiv a license to display the preprint in perpetuity.

It is made available under a CC-BY-ND 4.0 International license .

53. Zheng X, Morrell J, Watts K. Changes in maternal self-efficacy, postnatal depression symptoms and social support among Chinese primiparous women during the initial postpartum period: A longitudinal study. Midwifery. 2018;62:151-60.

54. Racine N, Plamondon A, Hentges R, Tough S, Madigan S. Dynamic and bidirectional associations between maternal stress, anxiety, and social support: The critical role of partner and family support. Journal of Affective Disorders. 2019;252:19-24

55. Morikawa M, Okada T, Ando M, Aleksic B, Kunimoto S, Nakamura Y, et al. Relationship between social support during pregnancy and postpartum depressive state: A prospective cohort study. Scientific Reports. $2015 ; 5(1): 1-9$.

56. Domènech-Abella J, Mundó J, Haro JM, Rubio-Valera M. Anxiety, depression, loneliness and social network in the elderly: Longitudinal associations from The Irish Longitudinal Study on Ageing (TILDA). Journal of Affective Disorders. 2019;246:82-8.

57. Evans IE, Llewellyn DJ, Matthews FE, Woods RT, Brayne C, Clare L. Social isolation, cognitive reserve, and cognition in older people with depression and anxiety. Aging \& Mental Health. 2019;23(12):1691-700.

58. Herbolsheimer F, Ungar N, Peter R. Why is social isolation among older adults associated with depressive symptoms? The mediating role of out-of-home physical activity. International Journal of Behavioral

60. Chang SC, Pan A, Kawachi I, Okereke OI. Risk factors for late-life depression: A prospective cohort study Medicine. 2018;25(6):649-57.

59. Holvast F, Burger H, de Waal MM, van Marwijk HW, Comijs HC, Verhaak PF. Loneliness is associated with poor prognosis in late-life depression: Longitudinal analysis of the Netherlands study of depression in older among older women. Preventive Medicine. 2016;91:144-51. their impact on the social network and depression-results of the Leipzig Longitudinal Study of the Aged (LEILA 75+). Journal of Affective Disorders. 2018;241:94-102. 10-year cross-lagged analysis. Psychology and Aging. 2020;35(7):948-962. 
medRxiv preprint doi: https://doi.org/10.1101/2022.01.26.22269896; this version posted January 28, 2022. The copyright holder for this preprint (which was not certified by peer review) is the author/funder, who has granted medRxiv a license to display the preprint in perpetuity.

It is made available under a CC-BY-ND 4.0 International license .

63. Santini ZI, Jose PE, Cornwell EY, Koyanagi A, Nielsen L, Hinrichsen C, et al. Social disconnectedness, perceived isolation, and symptoms of depression and anxiety among older Americans (NSHAP): A longitudinal mediation analysis. The Lancet Public Health. 2020;5(1):e62-70.

64. Lund C, Brooke-Sumner C, Baingana F, Baron EC, Breuer E, Chandra P, et al. Social determinants of mental disorders and the sustainable development goals: A systematic review of reviews. Lancet Psychiatry. 2018;5(4):357-369.

65. Saeri AK, Cruwys T, Barlow FK, Stronge S, Sibley CG. Social connectedness improves public mental health: Investigating bidirectional relationships in the New Zealand attitudes and values survey. Australian \& New Zealand Journal of Psychiatry. 2018;52(4):365-74.

66. Due TD, Sandholdt H, Siersma D, Waldroff FB. How well do general practitioners know their elderly patients' social relations and feelings of loneliness? BMC Family Pract. 2018;19:34.

67. Pantell M, Rehkopf D, Jutte D, Syme SL, Balmes J, Adler N. Social isolation: a predictor of mortality comparable to traditional clinical risk factors. Am J Public Health. 2013;103(11):2056-62. DiMatteo MR. Social support and patient adherence to medical treatment: A meta-analysis. Health Psychol. 2004; 23(2):207218.

68. Dykstra PA, van Tilburg TG, de Jong Gierveld J. Changes in older adult loneliness: Results from a sevenyear longitudinal study. Res Aging. 2005; 27(6):725-747.

69. Wrzus C, Wagner J, Hänel M, Neyer FJ. Social network changes and life events across the life span: A metaanalysis. Psychol Bull. 2013; 139(1):53-80.

70. Goossens L, van Roekel E, Verhagen M, Cacioppo JT, Cacioppo S, Maes M, Boomsma DI. The genetics of loneliness: linking evolutionary theory to genome-wide genetics, epigenetics, and social science. Perspect Psychol Sci. 2015;10(2):213-26. 
Table 1a. Characteristics of included studies on social support for nonpregnant samples

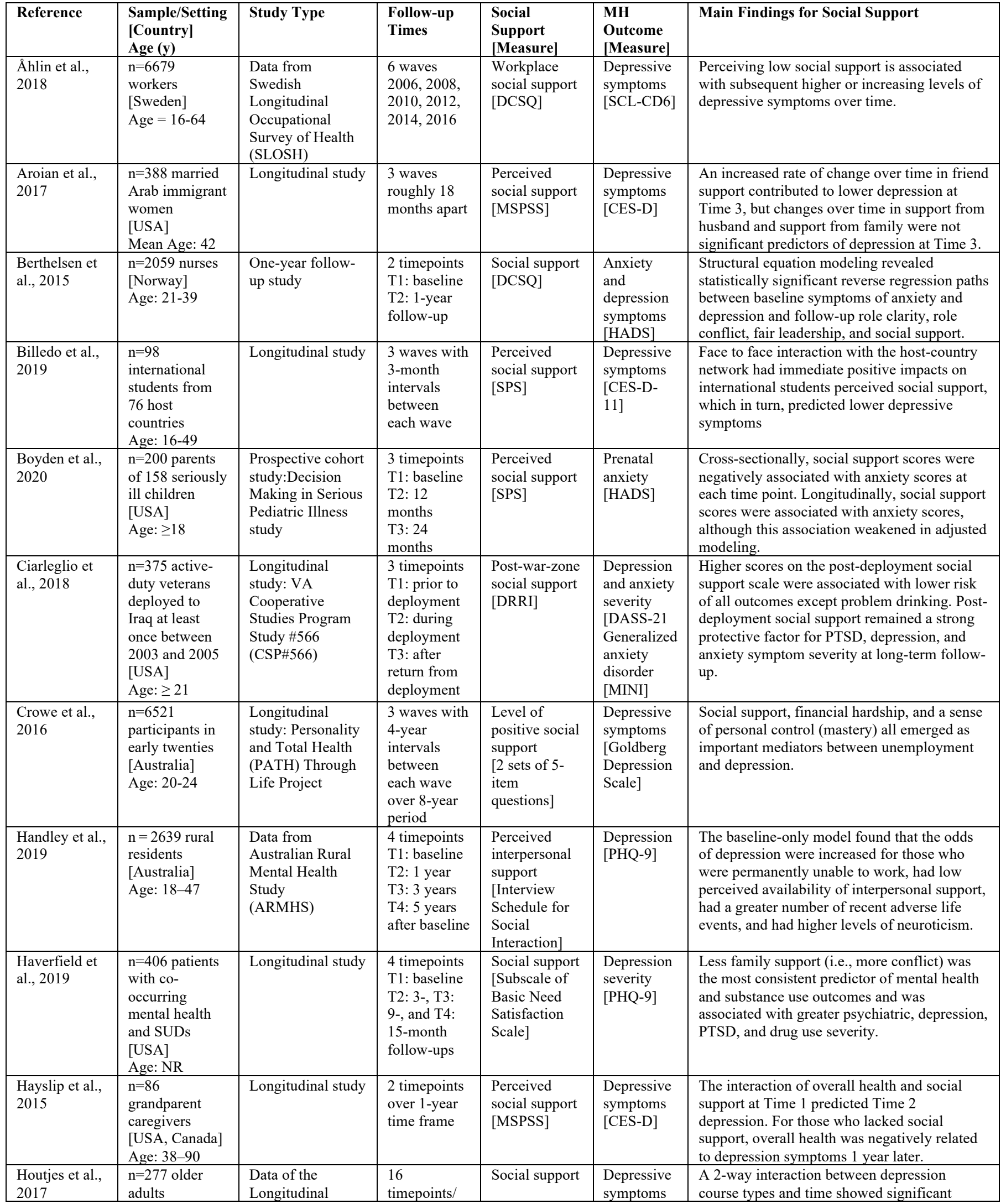




\begin{tabular}{|c|c|c|c|c|c|c|}
\hline & $\begin{array}{l}\text { [Amsterdam] } \\
\text { Age: }>55\end{array}$ & $\begin{array}{l}\text { Aging Study } \\
\text { Amsterdam } \\
\text { (LASA) }\end{array}$ & $\begin{array}{l}\text { observations } \\
\text { covering } 13 \\
\text { years }\end{array}$ & $\begin{array}{l}\text { [Self-reported } \\
\text { questionnaire] }\end{array}$ & [CES-D] & $\begin{array}{l}\text { differences in instrumental support received } \\
\text { over time in older people with a late-life } \\
\text { depression. }\end{array}$ \\
\hline $\begin{array}{l}\text { Misawa et al., } \\
2019\end{array}$ & $\begin{array}{l}\mathrm{n}=3464 \text { elderly } \\
\text { people } \\
\text { [Japan] } \\
\text { Age: } \geq 65\end{array}$ & $\begin{array}{l}\text { Longitudinal panel } \\
\text { data: Part of Aichi } \\
\text { Gerontological } \\
\text { Evaluation Study } \\
\text { (AGES) project }\end{array}$ & $\begin{array}{l}2 \text { waves. } \\
2003,2006- \\
2007\end{array}$ & $\begin{array}{l}\text { Social support } \\
\text { [Self-reported } \\
\text { questionnaire] }\end{array}$ & $\begin{array}{l}\text { Depression } \\
\text { [GDS-15] }\end{array}$ & $\begin{array}{l}\text { The frequency of meeting with friends and } \\
\text { self-rated health predicted reduced odds of } \\
\text { depression in men, while age predicted } \\
\text { increased odds in women. }\end{array}$ \\
\hline $\begin{array}{l}\text { Noteboom et } \\
\text { al., } 2016\end{array}$ & $\begin{array}{l}\mathrm{n}=1085 \\
\text { respondents } \\
\text { from health } \\
\text { care settings } \\
\text { [Netherlands] } \\
\text { Age: }>18\end{array}$ & $\begin{array}{l}\text { Longitudinal } \\
\text { cohort study: } \\
\text { Netherlands Study } \\
\text { of Depression and } \\
\text { Anxiety (NESDA) }\end{array}$ & $\begin{array}{l}2 \text { timepoints } \\
\text { T1: baseline } \\
\text { T2: 2-year } \\
\text { follow-up }\end{array}$ & $\begin{array}{l}\text { Social support } \\
{[\mathrm{CPQ}]}\end{array}$ & $\begin{array}{l}\text { Depressive } \\
\text { disorders } \\
\text { [CIDI] }\end{array}$ & $\begin{array}{l}\text { Contrary to authors' expectations, low } \\
\text { perceived support, or the perceived aspects } \\
\text { (perceived emotional support or negative } \\
\text { aspects of support) are not associated with the } \\
\text { development of a new episode of depression } \\
\text { after accounting for baseline clinical } \\
\text { characteristics }\end{array}$ \\
\hline $\begin{array}{l}\text { Van Den } \\
\text { Brink et al., } \\
2018\end{array}$ & $\begin{array}{l}\mathrm{n}=1474 \text { patients } \\
\text { with MDD } \\
\text { Sample 1: } 1115 \\
\text { patients } \\
\text { Sample } 2: 359 \\
\text { patients } \\
\text { [Netherlands] } \\
\text { Age: } 18-90\end{array}$ & $\begin{array}{l}\text { Data from two } \\
\text { cohort studies } \\
\text { Sample1: NESDA } \\
\text { Sample 2: } \\
\text { Netherlands Study } \\
\text { of Depression in } \\
\text { Older Persons } \\
\text { (NESDO) }\end{array}$ & & $\begin{array}{l}\text { Social support } \\
\text { received from } \\
\text { partner and } \\
\text { from closest } \\
\text { friend or } \\
\text { family } \\
\text { member } \\
\text { [CPQ] }\end{array}$ & $\begin{array}{l}\text { Presence of } \\
\text { depression } \\
\text { [CIDI] } \\
\text { Depression } \\
\text { severity } \\
\text { [IDS-SR] }\end{array}$ & $\begin{array}{l}\text { Negative experiences with social support were } \\
\text { the only social relational variable, which } \\
\text { independently predicted non-remission of } \\
\text { depression at follow-up. }\end{array}$ \\
\hline $\begin{array}{l}\text { Porter et al., } \\
2017\end{array}$ & $\begin{array}{l}\mathrm{n}=343 \\
\text { undergraduates } \\
\text { and their } \\
\text { romantic } \\
\text { partners } \\
\text { [USA] } \\
\text { Age: } 18-23\end{array}$ & Longitudinal study & $\begin{array}{l}2 \text { timepoints } \\
\text { T1: baseline } \\
\text { T2: } 12- \\
\text { month } \\
\text { follow-up }\end{array}$ & $\begin{array}{l}\text { Perceived } \\
\text { social support } \\
\text { [MSPSS] }\end{array}$ & $\begin{array}{l}\text { Social } \\
\text { anxiety } \\
\text { [SIAS] } \\
\text { Depression, } \\
\text { anxiety } \\
\text { symptoms } \\
\text { [DASS-21] }\end{array}$ & $\begin{array}{l}\text { Social anxiety is not associated with less } \\
\text { support as rated by observers. Socially anxious } \\
\text { individuals received less support from their } \\
\text { partners according to participant but not } \\
\text { observer report. }\end{array}$ \\
\hline $\begin{array}{l}\text { Scardera et } \\
\text { al., } 2020\end{array}$ & $\begin{array}{l}\mathrm{n}=1174 \\
\text { emerging adults } \\
\text { [Canada] } \\
\text { Age: } 19-20\end{array}$ & $\begin{array}{l}\text { Population-based } \\
\text { cohort study: Data } \\
\text { from Quebec } \\
\text { Longitudinal } \\
\text { Study of Child } \\
\text { Development }\end{array}$ & $\begin{array}{l}2 \text { timepoints } \\
\text { T1: baseline } \\
\text { T2: } 1 \text { year } \\
\text { later }\end{array}$ & $\begin{array}{l}\text { Perceived } \\
\text { social support } \\
\text { [SPS-10] }\end{array}$ & $\begin{array}{l}\text { Depressive } \\
\text { symptoms } \\
\text { [CES-D] } \\
\text { Anxiety } \\
\text { symptoms } \\
\text { [GAD-7] }\end{array}$ & $\begin{array}{l}\text { Perceived social support was significantly } \\
\text { associated with fewer depressive and anxiety } \\
\text { symptoms, and suicide-related outcomes at 1- } \\
\text { year follow-up. The magnitude of these } \\
\text { associations appears stronger for depressive } \\
\text { symptoms compared with anxiety symptoms. }\end{array}$ \\
\hline $\begin{array}{l}\text { Whitley et al., } \\
2016\end{array}$ & $\begin{array}{l}\mathrm{n}=667 \text { African } \\
\text { American } \\
\text { custodial } \\
\text { grandmothers } \\
\text { [USA] } \\
\text { Age: } 33-83 \\
\end{array}$ & Prospective study & $\begin{array}{l}2 \text { timepoints } \\
\text { T1: baseline } \\
\text { T2: } 12- \\
\text { month } \\
\text { follow-up }\end{array}$ & $\begin{array}{l}\text { Social support } \\
\text { [FSS] }\end{array}$ & $\begin{array}{l}\text { Depression } \\
\text { severity } \\
\text { [BSI] }\end{array}$ & $\begin{array}{l}\text { Social support was a mediator in the } \\
\text { association between depressive symptoms and } \\
\text { mental health quality of life for older African } \\
\text { American grandmothers }(55+) \text {; however, this } \\
\text { same relationship did not hold for their } \\
\text { younger counterparts }(\leq 55) \text {. }\end{array}$ \\
\hline $\begin{array}{l}\text { Zhou et al., } \\
2020\end{array}$ & $\begin{array}{l}\mathrm{n}=1137 \text { college } \\
\text { freshmen } \\
{[\text { China }]} \\
\text { Age: } \geq 18\end{array}$ & Panel study & $\begin{array}{l}3 \text { waves with } \\
1 \text { month } \\
\text { interval } \\
\text { between } \\
\text { each wave }\end{array}$ & $\begin{array}{l}\text { Perceived } \\
\text { Family } \\
\text { Support } \\
\text { [MSPSS] }\end{array}$ & $\begin{array}{l}\text { Depression } \\
\text { severity } \\
\text { [PHQ-9] }\end{array}$ & $\begin{array}{l}\text { Family support in Wave } 1 \text { decreased } \\
\text { compensatory social networking sites (SNS) } \\
\text { use for less introverted freshmen in Wave } 2 \\
\text { and further decreased depression in Wave } 3 \text {. }\end{array}$ \\
\hline \multicolumn{7}{|c|}{$\begin{array}{l}\text { Checklist: BSI = Brief Symptom Inventory; CES-D = Center for Epidemiological Studies-Depression Scale; CIDI = Composite International Diagnostic } \\
\text { Interview; DASS = Depression Anxiety Stress Scale; DCSQ = Demand-Control-Support-Questionnaire; DRRI = Deployment Risk and Resilience Inventory; } \\
\text { FSS = Family Support Scale; GAD = Generalized Anxiety Disorder; HADS = Hospital Anxiety and Depression Scale; IDS-SR = Inventory of Depressive } \\
\text { Symptomatology Self-Report version; MINI: Mini-International Neuropsychiatric Interview; MSPSS = Multidimensional Scale of Perceived Social Support; } \\
\text { PHQ = Patient Health Questionnaire; SCL-CD6 =Symptom Checklist Core Depression Scale; SIAS = Social Interaction Anxiety Scale; SPS = Social } \\
\text { Provisions Scale }\end{array}$} \\
\hline
\end{tabular}




\begin{tabular}{|c|c|c|c|c|c|c|}
\hline Reference & $\begin{array}{l}\text { Sample/Setting } \\
\text { [Country] }\end{array}$ & Study Type & $\begin{array}{l}\text { Follow-up } \\
\text { Times }\end{array}$ & $\begin{array}{l}\text { Social } \\
\text { Support } \\
\text { [Measure] }\end{array}$ & $\begin{array}{l}\text { MH } \\
\text { Outcome } \\
\text { [Measure] }\end{array}$ & Main Findings for Social Support \\
\hline $\begin{array}{l}\text { Albuja et al., } \\
2017\end{array}$ & $\begin{array}{l}\mathrm{n}=210 \text { women } \\
\text { from two } \\
\text { clinics that } \\
\text { provide prenatal } \\
\text { care [Mexico] } \\
\text { Age: } 20-44\end{array}$ & $\begin{array}{l}\text { Longitudinal } \\
\text { study }\end{array}$ & $\begin{array}{l}\text { T1: } 3^{\text {rd }} \text { trimester } \\
\text { T2: } 6 \text { months } \\
\text { postpartum }\end{array}$ & $\begin{array}{l}\text { Social Support } \\
\text { [PDPI-R } \\
\text { social support } \\
\text { subscale] }\end{array}$ & $\begin{array}{l}\text { Depressive } \\
\text { symptoms } \\
\text { [PHQ-9] }\end{array}$ & $\begin{array}{l}\text { Lacking social support during the } 3^{\text {rd }} \\
\text { trimester of pregnancy was associated with } \\
\text { greater depressive symptoms at } 6 \text { months in } \\
\text { the postpartum, although this relationship } \\
\text { depended on the level of endorsement of the } \\
\text { traditional female role during pregnancy. }\end{array}$ \\
\hline $\begin{array}{l}\text { Asselmann et } \\
\text { al., } 2016\end{array}$ & \multirow{2}{*}{$\begin{array}{l}\mathrm{n}=306 \\
\text { expectant } \\
\text { mothers } \\
\text { sampled from } \\
\text { community in } \\
\text { gynecological } \\
\text { outpatient } \\
\text { settings } \\
\text { [Germany] } \\
\text { Age: } 18-40\end{array}$} & \multirow[t]{2}{*}{$\begin{array}{l}\text { Prospective- } \\
\text { longitudinal } \\
\text { Maternal } \\
\text { Anxiety in } \\
\text { Relation to } \\
\text { Infant } \\
\text { Development } \\
\text { (MARI) Study }\end{array}$} & \multirow{2}{*}{$\begin{array}{l}\text { T1: week 10-12 } \\
\text { gestation } \\
\text { T2: week } 22-24 \\
\text { gestation } \\
\text { T3: week } 35-37 \\
\text { gestation } \\
\text { T4: } 10 \text { days } \\
\text { postpartum } \\
\text { T5: } 2 \text { months } \\
\text { postpartum } \\
\text { T6: } 4 \text { months } \\
\text { postpartum } \\
\text { T7: } 16 \text { months } \\
\text { postpartum }\end{array}$} & \multirow[t]{2}{*}{$\begin{array}{l}\text { Perceived } \\
\text { Social Support } \\
\text { [F-SozU K- } \\
14]\end{array}$} & $\begin{array}{l}\text { Maternal } \\
\text { depressive } \\
\text { and anxiety } \\
\text { disorders } \\
{[\text { CIDI-V] }}\end{array}$ & $\begin{array}{l}\text { Perceived social support declined from } \\
\text { prepartum to postpartum; levels of prepartum } \\
\text { and postpartum social support were lower in } \\
\text { women with comorbid anxiety and } \\
\text { depressive disorders compared to those with } \\
\text { pure depressive disorder(s), pure anxiety } \\
\text { disorder(s), or comorbid anxiety and } \\
\text { depressive disorders prior to pregnancy. }\end{array}$ \\
\hline $\begin{array}{l}\text { Asselmann et } \\
\text { al., } 2020\end{array}$ & & & & & $\begin{array}{l}\text { Depressive, } \\
\text { anxiety, } \\
\text { and stress } \\
\text { symptoms } \\
\text { [DASS-21] }\end{array}$ & $\begin{array}{l}\text { Peripartum depressive, anxiety, and stress } \\
\text { symptoms were lower in women with higher } \\
\text { perceived social support } \\
(b=-0.225 \text { to }-0.308)\end{array}$ \\
\hline $\begin{array}{l}\text { Cankorur et } \\
\text { al., } 2015\end{array}$ & $\begin{array}{l}\mathrm{n}=730 \text { women } \\
\text { from } 20 \text { urban } \\
\text { and rural } \\
\text { antenatal } \\
\text { clinics } \\
\text { [Turkey] } \\
\text { Age: } 18-44\end{array}$ & Cohort study & $\begin{array}{l}\text { T1: } 3^{\text {rd }} \text { trimester } \\
\text { T2: } 2 \text { months } \\
\text { after childbirth } \\
\text { T3: } 6 \text { months } \\
\text { after childbirth }\end{array}$ & $\begin{array}{l}\text { Emotional, } \\
\text { practical } \\
\text { support } \\
\text { [CPQ] }\end{array}$ & $\begin{array}{l}\text { Depressive } \\
\text { symptoms } \\
\text { [EPDS] }\end{array}$ & $\begin{array}{l}\text { Worse emotional support from mother-in-law } \\
\text { was significantly associated with postnatal } \\
\text { depression incidence (OR }=0.93,95 \% \text { CI } 0.87 \\
\text { to } 0.99 \text { ) and worse emotional support from } \\
\text { husband with postnatal persistence } \\
(\mathrm{OR}=0.89,95 \% \text { CI } 0.83 \text { to } 0.96 \text { ) of antenatal } \\
\text { depression. }\end{array}$ \\
\hline $\begin{array}{l}\text { Chen et al., } \\
2016\end{array}$ & $\begin{array}{l}\mathrm{n}=203 \text { South } \\
\text { Asia immigrant } \\
\text { mothers } \\
\text { [Taiwan] } \\
\text { Age: } \geq 18\end{array}$ & Panel study & $\begin{array}{l}\text { T1: } 1 \text { month } \\
\text { postpartum } \\
\text { T2: } 6 \text { months } \\
\text { postpartum } \\
\text { T3: } 1 \text { year } \\
\text { postpartum }\end{array}$ & $\begin{array}{l}\text { Emotional, } \\
\text { instrumental, } \\
\text { informational } \\
\text { support } \\
\text { [Social } \\
\text { Support Scale] }\end{array}$ & $\begin{array}{l}\text { Depressive } \\
\text { symptoms } \\
\text { [EPDS] }\end{array}$ & $\begin{array}{l}\text { Depression and instrumental support } \\
\text { followed downward curvilinear trajectories, } \\
\text { while emotional and informational support } \\
\text { followed upward curvilinear trajectories. } \\
\text { Emotional and instrumental support } \\
\text { negatively covaried with postpartum } \\
\text { depression over time, but not informational } \\
\text { support. }\end{array}$ \\
\hline $\begin{array}{l}\text { Chen et al., } \\
2020\end{array}$ & $\begin{array}{l}\mathrm{n}=407 \\
\text { immigrant and } \\
\text { native-born } \\
\text { women from } \\
\text { obstetrical } \\
\text { clinics and } \\
\text { hospitals } \\
\text { [Taiwan] } \\
\text { Age: } 20-44\end{array}$ & $\begin{array}{l}\text { Prospective } \\
\text { study }\end{array}$ & $\begin{array}{l}\mathrm{T} 1: 2^{\text {nd }} \text { or } 3^{\text {rd }} \\
\text { trimester } \\
\mathrm{T} 2: 3 \text { months } \\
\text { postpartum }\end{array}$ & $\begin{array}{l}\text { Emotional, } \\
\text { instrumental, } \\
\text { informational } \\
\text { support } \\
\text { [Social } \\
\text { Support Scale] }\end{array}$ & $\begin{array}{l}\text { Depressive } \\
\text { symptoms } \\
\text { [EPDS] }\end{array}$ & $\begin{array}{l}\text { Social support was significantly and } \\
\text { negatively associated with postpartum } \\
\text { depressive symptoms in both immigrant and } \\
\text { the native-born women, and presence of } \\
\text { depressive symptomatology during } \\
\text { pregnancy and a lower level of social support } \\
\text { were associated with an increased depressive } \\
\text { symptom score at } 3 \text { months postpartum. }\end{array}$ \\
\hline $\begin{array}{l}\text { Faleschini et } \\
\text { al., } 2020\end{array}$ & $\begin{array}{l}\mathrm{n}=1356 \text { women } \\
\text { from } 8 \text { obstetric } \\
\text { offices } \\
\text { [USA] } \\
\text { Mean age: } 32.6\end{array}$ & $\begin{array}{l}\text { Data from } \\
\text { Project Viva, } \\
\text { a prospective } \\
\text { observational } \\
\text { cohort study } \\
\end{array}$ & $\begin{array}{l}\text { T1: trimester } \\
\text { visits } \\
\text { T1: } 6 \text { months } \\
\text { postpartum }\end{array}$ & $\begin{array}{l}\text { Perceived } \\
\text { social support } \\
\text { [Turner } \\
\text { Support Scale] }\end{array}$ & $\begin{array}{l}\text { Depressive } \\
\text { symptoms } \\
\text { [EPDS] }\end{array}$ & $\begin{array}{l}\text { Greater partner support and support from } \\
\text { family/friends were strongly associated with } \\
\text { lower odds of incident depression (OR } 0.33 \text {, } \\
95 \% \text { CI }[0.20,0.55] \text { and OR } 0.49,95 \% \text { CI } \\
[0.30,0.79]) \text {. }\end{array}$ \\
\hline $\begin{array}{l}\text { Gan et al., } \\
2019\end{array}$ & $\begin{array}{l}\mathrm{n}=3310 \text { women } \\
\text { from antenatal } \\
\text { clinics } \\
{[\text { China }]} \\
\text { Age: } \geq 20\end{array}$ & $\begin{array}{l}\text { Prospective } \\
\text { study; Data } \\
\text { from Shanghai } \\
\text { Birth Cohort }\end{array}$ & $\begin{array}{l}\text { T1: early } \\
\text { pregnancy } \\
\text { T2: } 6 \text { weeks } \\
\text { postpartum }\end{array}$ & $\begin{array}{l}\text { Perceived } \\
\text { social support } \\
{[\text { ESSI] }}\end{array}$ & $\begin{array}{l}\text { Postpartum } \\
\text { depression } \\
\text { [EPDS] }\end{array}$ & $\begin{array}{l}\text { Significant associations between low } \\
\text { perceived social support and postpartum } \\
\text { depressive symptoms were found (Model I } \\
\text { odds ratio: } 1.63,95 \% \text { confidence interval: } \\
1.15,2.30 \text {; Model II odds ratio: } 1.77,95 \% \\
\text { confidence interval: } 1.24-2.52 \text { ). }\end{array}$ \\
\hline Hare, 2020 & $\begin{array}{l}\mathrm{n}=144 \text { women } \\
\text { at risk for } \\
\text { peripartum } \\
\text { depression/ } \\
\text { euthymic } \\
\text { [USA] } \\
\text { Age: } 19-41\end{array}$ & Cohort study & $\begin{array}{l}\text { T1 \& T2: } \\
\text { Twice } \\
\text { antepartum } \\
\text { T3 \& T4: } \\
\text { Twice } \\
\text { postpartum }\end{array}$ & $\begin{array}{l}\text { Perceived } \\
\text { social support } \\
{[\text { PSSQ] }}\end{array}$ & $\begin{array}{l}\text { Peripartum } \\
\text { depression } \\
\text { [EPDS] } \\
\text { Anxiety } \\
\text { [HAM-A] }\end{array}$ & $\begin{array}{l}\text { Women diagnosed with PND experienced } \\
\text { significantly worse mother-infant bonding } \\
\text { and social support compared to HCW } \\
(p=.001, p=.002 \text {, respectively) and to those } \\
\text { who were at-risk for but did not develop } \\
\text { PND }(p=.02, p=.008) \text {. }\end{array}$ \\
\hline
\end{tabular}




\begin{tabular}{|c|c|c|c|c|c|c|}
\hline $\begin{array}{l}\text { Hetherington } \\
\text { et al., } 2018\end{array}$ & $\begin{array}{l}\mathrm{n}=3057 \text { women } \\
{[\text { Canada }]} \\
\text { Age: } \geq 18\end{array}$ & $\begin{array}{l}\text { Data from the } \\
\text { All Our } \\
\text { Families } \\
\text { longitudinal } \\
\text { pregnancy } \\
\text { cohort }\end{array}$ & $\begin{array}{l}\text { T1: } 4 \text { months } \\
\text { postpartum } \\
\text { T2: } 1 \text { year } \\
\text { postpartum }\end{array}$ & $\begin{array}{l}\text { Support types: } \\
\text { tangible, } \\
\text { positive social } \\
\text { interaction, } \\
\text { and } \\
\text { emotional/info } \\
\text { rmational } \\
\text { support. } \\
\text { [MOS-SSS] }\end{array}$ & $\begin{array}{l}\text { Depressive } \\
\text { or anxiety } \\
\text { symptoms } \\
\text { [EPDS] }\end{array}$ & $\begin{array}{l}\text { Low total social support during pregnancy } \\
\text { was associated with increased risk of } \\
\text { depressive symptoms (RR } 1.50,95 \% \text { CI } 1.24 \\
\text { to } 1.82 \text { ) and anxiety symptoms (RR } 1.63 \text {, } \\
95 \% \text { CI } 1.38 \text { to } 1.93 \text { ) at } 4 \text { months } \\
\text { postpartum. Low total social support at } 4 \\
\text { months was associated with increased risk of } \\
\text { anxiety symptoms (RR } 1.65,95 \% \text { CI } 1.31 \text { to } \\
2.09 \text { ) at } 1 \text { year. Emotional or informational } \\
\text { support wan an important type of support for } \\
\text { postpartum anxiety. }\end{array}$ \\
\hline $\begin{array}{l}\text { Leonard et al., } \\
2020\end{array}$ & $\begin{array}{l}\mathrm{n}=1316 \text { first } \\
\text { time mothers } \\
\text { [USA] } \\
\text { Age: } 18-35\end{array}$ & $\begin{array}{l}\text { Longitudinal } \\
\text { cohort study }\end{array}$ & $\begin{array}{l}5 \text { Time points: } \\
1,6,12,18, \text { and } \\
24 \text { months } \\
\text { postpartum }\end{array}$ & $\begin{array}{l}\text { Perceived } \\
\text { social support } \\
\text { [MOS-SSS] }\end{array}$ & $\begin{array}{l}\text { Maternal } \\
\text { postpartum } \\
\text { depressive } \\
\text { symptoms } \\
{[\text { EPDS] }}\end{array}$ & $\begin{array}{l}\text { Perceived social support decreased, } \\
\text { perceived stress increased, and depressive } \\
\text { symptoms remained constant from } 1 \text { to } 18 \\
\text { months, then increased at } 24 \text { months. Low } \\
\text { perceived social support predicted } 6 \text {-month } \\
\text { depressive symptoms, whereas perceived } \\
\text { stress predicted depressive symptoms at all } \\
\text { time points. }\end{array}$ \\
\hline Li et al., 2017 & $\begin{array}{l}\mathrm{n}=240 \text { pregnant } \\
\text { women from } \\
\text { the prenatal } \\
\text { clinic at a } \\
\text { general hospital } \\
\text { [China] } \\
\text { Age: } \geq 18\end{array}$ & $\begin{array}{l}\text { Longitudinal } \\
\text { study }\end{array}$ & $\begin{array}{l}\text { T1: late } \\
\text { pregnancy } \\
\text { T2: 1 week } \\
\text { postpartum } \\
\text { T3: } 4 \text { weeks } \\
\text { postpartum }\end{array}$ & $\begin{array}{l}\text { Perceived } \\
\text { social support } \\
\text { [MSPSS] }\end{array}$ & $\begin{array}{l}\text { Antepartum } \\
\text { depression } \\
\text { [EPDS] }\end{array}$ & $\begin{array}{l}\text { Women who had higher Perceived Social } \\
\text { Support Scale scores at late pregnancy had } \\
\text { less likelihood of developing antepartum } \\
\text { depression, and women with higher social } \\
\text { support scores at postpartum week } 4 \text { were } \\
\text { less likely to have postpartum depression. } \\
\text { However, the Perceived Social Support Scale } \\
\text { scores at late pregnancy did not predict the } \\
\text { risk of postpartum depression. }\end{array}$ \\
\hline $\begin{array}{l}\text { Milgrom et } \\
\text { al., } 2019\end{array}$ & $\begin{array}{l}\mathrm{n}=54 \text { women } \\
\text { who met DSM- } \\
\text { IV criteria of } \\
\text { MDD or minor } \\
\text { depression } \\
\text { [Australia] } \\
\text { Age: } \geq 18\end{array}$ & $\begin{array}{l}\text { Longitudinal } \\
\text { follow-up of a } \\
\text { previous RCT } \\
\text { for antenatal } \\
\text { depression }\end{array}$ & $\begin{array}{l}\text { T1: baseline } \\
\text { T2: } 9 \text { weeks } \\
\text { post- } \\
\text { randomization } \\
\text { T3: } 6 \text { months } \\
\text { T4: } 9 \text { months } \\
\text { T5: } 24 \text { months } \\
\text { post-birth }\end{array}$ & $\begin{array}{l}\text { Perceived } \\
\text { social support } \\
\text { [SPS] }\end{array}$ & $\begin{array}{l}\text { Depression } \\
\text { [BDI-II] } \\
\text { Anxiety } \\
{[\text { BAI }]}\end{array}$ & $\begin{array}{l}\text { Two aspects of social support, reassurance of } \\
\text { worth and reliable alliance, were strongly } \\
\text { related to perinatal depression and anxiety, } \\
\text { particularly when predicting symptoms in } \\
\text { late pregnancy. However, the effect of } \\
\text { postnatal depression on child development at } \\
\text { 9- and } 24 \text {-months post-birth was not } \\
\text { mediated by social support. }\end{array}$ \\
\hline $\begin{array}{l}\text { Morikawa et } \\
\text { al., } 2015\end{array}$ & $\begin{array}{l}\mathrm{n}=877 \text { women } \\
\text { enrolled in a } \\
\text { prepartum } \\
\text { program during } \\
\text { pregnancy } \\
\text { [Japan] } \\
\text { Age: } \geq 20\end{array}$ & Cohort study & $\begin{array}{l}\text { T1: before } \\
25^{\text {th }} \text { week of } \\
\text { gestation } \\
\text { T2: } 1 \text { month } \\
\text { after childbirth }\end{array}$ & $\begin{array}{l}\text { Social support } \\
\text { [SSQ] }\end{array}$ & $\begin{array}{l}\text { Postpartum } \\
\text { depression } \\
\text { [EPDS] }\end{array}$ & $\begin{array}{l}\text { Having a larger number of people available } \\
\text { to provide social support during pregnancy } \\
\text { has a greater protective effect on pregnant } \\
\text { mothers with than without depression. }\end{array}$ \\
\hline $\begin{array}{l}\text { Nakamura et } \\
\text { al., } 2020\end{array}$ & $\begin{array}{l}\mathrm{n}=12386 \\
\text { couples } \\
{[\text { France] }} \\
\text { Age: } \geq 18\end{array}$ & $\begin{array}{l}\text { Data from the } \\
\text { French } \\
\text { representative } \\
\text { ELFE (Etude } \\
\text { Longitudinale } \\
\text { Française } \\
\text { depuis } \\
\text { l'Enfance) } \\
\text { cohort study }\end{array}$ & $\begin{array}{l}\text { T1: at birth } \\
\text { T2: } 2 \text { months } \\
\text { post-partum } \\
\text { T3: 1year } \\
\text { postpartum } \\
\text { T4: } 2 \text { years } \\
\text { post-partum }\end{array}$ & $\begin{array}{l}\text { Informal and } \\
\text { formal support } \\
\text { [face-to-face } \\
\text { and phone } \\
\text { interviews] }\end{array}$ & $\begin{array}{l}\text { Parental } \\
\text { postnatal } \\
\text { depression } \\
\text { [EPDS] }\end{array}$ & $\begin{array}{l}\text { Insufficient partner support as well as } \\
\text { frequent quarrels during pregnancy predicted } \\
\text { the odds of both parents being depressed. } \\
\text { This association was higher for women with } \\
\text { psychological difficulties during pregnancy } \\
\text { than those without. An inverse association } \\
\text { was also observed between psychosocial risk } \\
\text { assessment attendance (informal support) and } \\
\text { joint parental PPD, especially in couples in } \\
\text { which the mother had psychological } \\
\text { difficulties during pregnancy. }\end{array}$ \\
\hline $\begin{array}{l}\text { Ohara et al., } \\
2017\end{array}$ & $\begin{array}{l}\mathrm{n}=494 \text { pregnant } \\
\text { women } \\
\text { attending } \\
\text { perinatal classes } \\
\text { [Japan] } \\
\text { Age: } \geq 20\end{array}$ & $\begin{array}{l}\text { Prospective } \\
\text { cohort study }\end{array}$ & $\begin{array}{l}\text { T1: early } \\
\text { pregnancy } \\
\text { before week } 25 \\
\text { T2: } 1 \text { month } \\
\text { after delivery }\end{array}$ & $\begin{array}{l}\text { Number of } \\
\text { persons and } \\
\text { satisfaction } \\
\text { with social } \\
\text { support } \\
\text { [SSQ] }\end{array}$ & $\begin{array}{l}\text { Postpartum } \\
\text { depression } \\
\text { [EPDS] }\end{array}$ & $\begin{array}{l}\text { Satisfaction with the social support received } \\
\text { during pregnancy did not directly predict } \\
\text { depression in the postpartum period at a } \\
\text { statistically significant level. However, } \\
\text { poorer satisfaction with the social support } \\
\text { received during pregnancy was a cause of } \\
\text { depression in the postpartum period due to } \\
\text { increased depression during pregnancy. }\end{array}$ \\
\hline
\end{tabular}




\begin{tabular}{|c|c|c|c|c|c|c|}
\hline $\begin{array}{l}\text { Ohara et al., } \\
2018\end{array}$ & $\begin{array}{l}\mathrm{n}=855 \text { pregnant } \\
\text { women } \\
\text { attending } \\
\text { perinatal classes } \\
\text { [Japan] } \\
\text { Age: } \geq 20\end{array}$ & Cohort study & $\begin{array}{l}\text { T1: early } \\
\text { pregnancy } \\
\text { before week } 25 \\
\text { T2: } 1 \text { month } \\
\text { after delivery }\end{array}$ & $\begin{array}{l}\text { Number of } \\
\text { persons and } \\
\text { satisfaction } \\
\text { with social } \\
\text { support } \\
\text { [SSQ] }\end{array}$ & $\begin{array}{l}\text { Postpartum } \\
\text { depression } \\
\text { [EPDS] }\end{array}$ & $\begin{array}{l}\text { Bonding failure in the postpartum period was } \\
\text { significantly influenced by mothers' own } \\
\text { perceived rearing as well as social support } \\
\text { during pregnancy. In addition, depression in } \\
\text { the postpartum period was strongly } \\
\text { influenced by social support during } \\
\text { pregnancy }\end{array}$ \\
\hline $\begin{array}{l}\text { Racine et al., } \\
2019\end{array}$ & $\begin{array}{l}\mathrm{n}=3388 \\
\text { mothers from } \\
\text { community, } \\
\text { laboratory, and } \\
\text { health care } \\
\text { clinic offices } \\
\text { [Canada] } \\
\text { Age: } \geq 18\end{array}$ & $\begin{array}{l}\text { Large, } \\
\text { population- } \\
\text { based cohort } \\
\text { All Our } \\
\text { Babies/Famili } \\
\text { es } \\
(\mathrm{AOB} / \mathrm{AOF})\end{array}$ & $\begin{array}{l}\text { T1: }<25 \text { weeks } \\
\text { gestation } \\
\text { T2: } 34-36 \\
\text { weeks gestation } \\
\text { T3: } 4 \text { months } \\
\text { postpartum } \\
\text { T4: } 12 \text { months } \\
\text { postpartum }\end{array}$ & $\begin{array}{l}\text { Perceived } \\
\text { social support: } \\
\text { [3 questions] }\end{array}$ & $\begin{array}{l}\text { Prenatal } \\
\text { and } \\
\text { postpartum } \\
\text { anxiety } \\
\text { [STAI] }\end{array}$ & $\begin{array}{l}\text { Women who experience heightened stress } \\
\text { and anxiety in the perinatal period relative to } \\
\text { their own average levels are at risk of higher } \\
\text { anxiety and stress at subsequent time points; } \\
\text { within-person increases in partner and friend } \\
\text { support are salient predictors of subsequent } \\
\text { decreases in both stress and anxiety; } \\
\text { increases in stress and anxiety in the perinatal } \\
\text { period are at risk of experiencing decreases } \\
\text { in friend and family support. }\end{array}$ \\
\hline $\begin{array}{l}\text { Racine et al., } \\
2020\end{array}$ & $\begin{array}{l}\mathrm{n}=1994 \text { women } \\
\text { from health } \\
\text { care and } \\
\text { laboratory } \\
\text { offices } \\
\text { [Canada] } \\
\text { Age: } \geq 18\end{array}$ & $\begin{array}{l}\text { Large, } \\
\text { population- } \\
\text { based cohort } \\
\text { All Our } \\
\text { Babies/Famili } \\
\text { es } \\
(\mathrm{AOB} / \mathrm{AOF})\end{array}$ & $\begin{array}{l}\text { T1: }<25 \text { weeks } \\
\text { gestation } \\
\text { T2: } 4 \text { months } \\
\text { postpartum } \\
\text { T2: infant age } \\
\text { of } 36 \text { months }\end{array}$ & $\begin{array}{l}\text { Maternal } \\
\text { social support } \\
\text { [MOS-SSS] }\end{array}$ & $\begin{array}{l}\text { Maternal } \\
\text { depression } \\
\text { [EPDS] }\end{array}$ & $\begin{array}{l}\text { Although maternal social support was a } \\
\text { significant predictor of maternal depression } \\
\text { across the perinatal period, social support did } \\
\text { not moderate the association between ACEs } \\
\text { and maternal depression. }\end{array}$ \\
\hline $\begin{array}{l}\text { Razurel et al., } \\
2015\end{array}$ & \multirow[t]{2}{*}{$\begin{array}{l}\mathrm{n}=235 \\
\text { primiparous } \\
\text { mothers } \\
\text { [Switzerland] } \\
\text { Age: } 21-43\end{array}$} & \multirow[t]{2}{*}{$\begin{array}{l}\text { Longitudinal } \\
\text { study }\end{array}$} & $\begin{array}{l}\text { T1: During the } \\
\text { last month of } \\
\text { pregnancy and } \\
\text { T2: } 6 \text { weeks } \\
\text { after birth }\end{array}$ & \multirow{2}{*}{$\begin{array}{l}\text { Satisfaction } \\
\text { with social } \\
\text { support } \\
\text { [20-items } \\
\text { scale } \\
\text { constructed in } \\
\text { the area of } \\
\text { perinatal care] }\end{array}$} & \multirow[t]{2}{*}{$\begin{array}{l}\text { Depressive } \\
\text { symptoms } \\
\text { [EPDS] } \\
\text { Anxiety } \\
\text { [STAI] }\end{array}$} & $\begin{array}{l}\text { Satisfaction with emotional support in } \mathrm{T} 1 \\
\text { was negatively correlated with depressive } \\
\text { symptoms in } \mathrm{T} 1 \text { and } \mathrm{T} 2 \text {, which suggested } \\
\text { that this type of support was important both } \\
\text { in the short and the } \\
\text { long term. }\end{array}$ \\
\hline $\begin{array}{l}\text { Razurel et al., } \\
2017\end{array}$ & & & $\begin{array}{l}\text { T1: gestational } \\
\text { weeks } 37-41 \\
\text { T2: } 2 \text { days post- } \\
\text { delivery } \\
\text { T3: } 6 \text { weeks } \\
\text { postpartum }\end{array}$ & & & $\begin{array}{l}\text { The more the women were provided with } \\
\text { support from their partners, the less } \\
\text { depressive symptoms and elevated levels of } \\
\text { anxiety they reported, even under stressful } \\
\text { conditions, while the satisfaction of support } \\
\text { from their mothers boosted their sense of } \\
\text { competency. Satisfaction with emotional } \\
\text { support from professionals tempered the } \\
\text { stress during the post-partum period }\left(\Delta \mathrm{R}^{2}=\right. \\
0.032 ; \mathrm{p}<.05) \text {. }\end{array}$ \\
\hline $\begin{array}{l}\text { Schwab-Reese } \\
\text { et al., } 2017\end{array}$ & $\begin{array}{l}\mathrm{n}=195 \text { women } \\
\text { from a large } \\
\text { hospital } \\
\text { [USA] } \\
\text { Age: } \geq 18\end{array}$ & $\begin{array}{l}\text { Longitudinal } \\
\text { study }\end{array}$ & $\begin{array}{l}\text { T1: following } \\
\text { birth } \\
\text { T2: } 3 \text { months } \\
\text { after birth } \\
\text { T3: } 6 \text { months } \\
\text { after birth }\end{array}$ & $\begin{array}{l}\text { Perceived } \\
\text { social support } \\
\text { [MOS-SSS] }\end{array}$ & $\begin{array}{l}\text { Depressive } \\
\text { and anxiety } \\
\text { symptoms } \\
\text { [DASS-21] }\end{array}$ & $\begin{array}{l}\text { Current perceptions of social support were } \\
\text { associated with depressive and anxiety } \\
\text { symptoms at three-months postpartum, but } \\
\text { social support was not protective against } \\
\text { depressive or anxiety symptoms at six- } \\
\text { months postpartum. }\end{array}$ \\
\hline $\begin{array}{l}\text { Senturk et al., } \\
2017\end{array}$ & $\begin{array}{l}\mathrm{n}=730 \text { women } \\
\text { recruited in } \\
\text { their third } \\
\text { trimester } \\
\text { [Turkey] } \\
\text { Age: } 18-44\end{array}$ & Cohort study & $\begin{array}{l}\text { T1: } 3^{\text {rd }} \text { trimester } \\
\text { T2: } 0.8-7.4 \\
\text { months after } \\
\text { childbirth } \\
\text { T3: } 10.8-16.6 \\
\text { months } \\
\text { T4: } 18.1-23.5 \\
\text { months }\end{array}$ & $\begin{array}{l}\text { Quality of } \\
\text { relationships } \\
\text { and social } \\
\text { support } \\
\text { [CPQ] }\end{array}$ & $\begin{array}{l}\text { Postpartum } \\
\text { depression } \\
\text { [EPDS] }\end{array}$ & $\begin{array}{l}\text { Self-rated emotional and practical support } \\
\text { from all three relationships worsened over } \\
\text { time in the cohort overall. Emotional support } \\
\text { from the husband, and emotional and } \\
\text { practical support from the mother-in-law } \\
\text { declined more strongly in women with } \\
\text { depressive symptoms at baseline }\end{array}$ \\
\hline $\begin{array}{l}\text { Tani et al., } \\
2017\end{array}$ & $\begin{array}{l}\mathrm{n}=179 \\
\text { nulliparous } \\
\text { pregnant } \\
\text { women } \\
\text { [Italy] } \\
\text { Age: } 18-42\end{array}$ & $\begin{array}{l}\text { Longitudinal } \\
\text { study }\end{array}$ & $\begin{array}{l}\text { T1: } 31-32 \text { week } \\
\text { of pregnancy } \\
\text { T2: } 1^{\text {st }} \text { day after } \\
\text { childbirth } \\
\text { T3: } 1 \text { month } \\
\text { after birth }\end{array}$ & $\begin{array}{l}\text { Perceived } \\
\text { social support } \\
\text { [MSSS] }\end{array}$ & $\begin{array}{l}\text { Postpartum } \\
\text { depression } \\
\text { [EPDS] }\end{array}$ & $\begin{array}{l}\text { Post-partum depression was influenced } \\
\text { negatively by maternal perceived social } \\
\text { support and positively by negative clinical } \\
\text { birth indices. In addition to these direct } \\
\text { effects, analyses revealed a significant effect } \\
\text { of maternal perceived social support on post- } \\
\text { partum depression, mediated by the clinical } \\
\text { indices considered. }\end{array}$ \\
\hline
\end{tabular}


medRxiv preprint doi: https://doi.org/10.1101/2022.01.26.22269896; this version posted January 28, 2022. The copyright holder for this preprint (which was not certified by peer review) is the author/funder, who has granted medRxiv a license to display the preprint in perpetuity.

It is made available under a CC-BY-ND 4.0 International license .

\begin{tabular}{|c|c|c|c|c|c|c|}
\hline $\begin{array}{l}\text { Tsai et al., } \\
2016\end{array}$ & $\begin{array}{l}\mathrm{n}=1238 \\
\text { pregnant in } \\
\text { economically } \\
\text { deprived } \\
\text { settlements } \\
\text { [South Africa] } \\
\text { Age: } \geq 18\end{array}$ & $\begin{array}{l}\text { Population- } \\
\text { based } \\
\text { longitudinal } \\
\text { study }\end{array}$ & $\begin{array}{l}\text { T1: } 6 \text { days after } \\
\text { birth } \\
\text { T2: } 6 \text { months } \\
\text { post-partum } \\
\text { T3: } 18 \text { months } \\
\text { post-partum } \\
\text { T4: } 36 \text {-month } \\
\text { follow-up }\end{array}$ & $\begin{array}{l}\text { Emotional and } \\
\text { instrumental } \\
\text { support } \\
\text { (10 questions } \\
\text { about trust and } \\
\text { support } \\
\text { derived from } \\
\text { SOS) }\end{array}$ & $\begin{array}{l}\text { Depression } \\
\text { symptom } \\
\text { severity } \\
\text { [EPDS] }\end{array}$ & $\begin{array}{l}\text { Social support was found to be an effect } \\
\text { modifier of the relationship between food } \\
\text { insufficiency and depression symptom } \\
\text { severity, consistent with the "buffering" } \\
\text { hypothesis. Instrumental support provided } \\
\text { buffering against the adverse impacts of food } \\
\text { insufficiency while emotional support did } \\
\text { not. }\end{array}$ \\
\hline $\begin{array}{l}\text { Yoruk et al., } \\
2020\end{array}$ & $\begin{array}{l}\mathrm{N}=317 \\
\text { pregnant } \\
\text { women at } 38 \\
\text { weeks of } \\
\text { gestation } \\
\text { [Turkey] } \\
\text { Age: } 23-34\end{array}$ & $\begin{array}{l}\text { Longitudinal } \\
\text { study }\end{array}$ & $\begin{array}{l}\text { T1: 4th week } \\
\text { postpartum } \\
\text { T2: 6th week } \\
\text { postpartum }\end{array}$ & $\begin{array}{l}\text { Perceived } \\
\text { social support } \\
\text { [MSPSS] }\end{array}$ & $\begin{array}{l}\text { Postpartum } \\
\text { depression } \\
\text { [EPDS] }\end{array}$ & $\begin{array}{l}\text { Despite the low level of perceived social } \\
\text { support in the group at risk for PPD, this } \\
\text { difference was not significant. }\end{array}$ \\
\hline $\begin{array}{l}\text { Zheng et al., } \\
2018\end{array}$ & $\begin{array}{l}\mathrm{n}=420 \text { Chinese } \\
\text { primiparous } \\
\text { women from } \\
\text { obstetric wards } \\
\text { at hospitals } \\
\text { [China] } \\
\text { Age: } \geq 18\end{array}$ & $\begin{array}{l}\text { Longitudinal } \\
\text { study }\end{array}$ & $\begin{array}{l}\text { T1: } 6 \text { weeks } \\
\text { postnatally } \\
\text { T2: } 12 \text { weeks } \\
\text { postnatally }\end{array}$ & $\begin{array}{l}\text { Emotional, } \\
\text { material, } \\
\text { informational, } \\
\text { and evaluation } \\
\text { of support } \\
\text { [PSSS] }\end{array}$ & $\begin{array}{l}\text { Postnatal } \\
\text { depression } \\
\text { symptoms } \\
\text { [EPDS] }\end{array}$ & $\begin{array}{l}\text { Postnatal depression symptoms and social } \\
\text { support are the important influencing factors } \\
\text { of maternal self-efficacy. The mean social } \\
\text { support scores and scores of emotional } \\
\text { support, informational support and evaluation } \\
\text { of support had statistically significant } \\
\text { increases over time. }\end{array}$ \\
\hline $\begin{array}{l}\text { Zhong et al., } \\
2018\end{array}$ & $\begin{array}{l}\mathrm{n}=3336 \text { women } \\
\text { [Peru] } \\
\text { Age: } 18-49\end{array}$ & $\begin{array}{l}\text { Pregnancy } \\
\text { Outcomes, } \\
\text { Maternal and } \\
\text { Infant Cohort } \\
\text { Study }\end{array}$ & $\begin{array}{l}\text { T1: }<16 \text { weeks } \\
\text { gestation } \\
\text { T2: } 26-28 \\
\text { weeks gestation }\end{array}$ & $\begin{array}{l}\text { Satisfaction } \\
\text { with social } \\
\text { support and } \\
\text { number of } \\
\text { support } \\
\text { providers } \\
\text { [SSQ-6] }\end{array}$ & $\begin{array}{l}\text { Depressive } \\
\text { symptoms } \\
\text { [EPDS] }\end{array}$ & $\begin{array}{l}\text { Low number of support providers at both } \\
\text { time points was associated with increased } \\
\text { risk of depression (odds ratio }=1.62,95 \% \\
\text { confidence interval: } 1.12,2.34 \text { ). Depression } \\
\text { risk was not significantly higher for women } \\
\text { who reported high social support at one of } \\
\text { the } 2 \text { time points. }\end{array}$ \\
\hline \multicolumn{7}{|c|}{$\begin{array}{l}\text { Checklist: BAI = Beck Anxiety Inventory; BDI = Beck Depression Inventory; CIDI = Composite International Diagnostic Interview for Women; CPQ = } \\
\text { Close Persons Questionnaire DASS = Depression Anxiety Stress Scale; EPDS = Edinburgh Postnatal Depression Scale; ESSI = ENRICHD Social Support } \\
\text { Instrument; F-SozU K-14 = Brief form of the Perceived Social Support Questionnaire; HAM-A = Hamilton Anxiety Rating Scale; MOS-SSS = Medical } \\
\text { Outcomes Study Social Support Survey; MSPSS = Multidimensional Scale of Perceived Social Support; MSSS = Maternal Social Support Scale; PDPI-R } \\
\text { = Postpartum Depression Predictors Inventory-Revised; PHQ = Patient Health Questionnaire; PSSQ = Postpartum Social Support Questionnaire; PSSS = } \\
\text { Postpartum Social Support Scale; SOS = Significant Others Scale; SPS = Social Provisions Scale; SSQ= Social Support Questionnaire; STAI = } \\
\text { Spielberger State Anxiety Scale }\end{array}$} \\
\hline
\end{tabular}


medRxiv preprint doi: https://doi.org/10.1101/2022.01.26.22269896; this version posted January 28, 2022. The copyright holder for this preprint (which was not certified by peer review) is the author/funder, who has granted medRxiv a license to display the preprint in perpetuity. It is made available under a CC-BY-ND 4.0 International license .

Table 2. Characteristics of included studies on social isolation

\begin{tabular}{|c|c|c|c|c|c|c|}
\hline Reference & $\begin{array}{l}\text { Sample/Setting } \\
\text { [Country] }\end{array}$ & Study Type & $\begin{array}{l}\text { Follow-up } \\
\text { Times }\end{array}$ & $\begin{array}{l}\text { Social } \\
\text { Isolation } \\
\text { [Measure] }\end{array}$ & $\begin{array}{l}\text { MH Outcome } \\
\text { [Measure] }\end{array}$ & Main Findings for Social Isolation \\
\hline $\begin{array}{l}\text { Domènech-Abella } \\
\text { et al., } 2019\end{array}$ & $\begin{array}{l}\mathrm{n}=5066 \text { adults } \\
\text { [Ireland] } \\
\text { age } \geq 50\end{array}$ & $\begin{array}{l}\text { Irish } \\
\text { Longitudinal } \\
\text { Study on } \\
\text { Ageing } \\
\text { (TILDA) }\end{array}$ & $\begin{array}{l}2 \text { waves of } \\
\text { TILDA } \\
\text { Second wave: } \\
2012-13 \\
\text { Third wave: } \\
2014-15\end{array}$ & $\begin{array}{l}\text { UCLA } \\
\text { Loneliness } \\
\text { Scale }\end{array}$ & $\begin{array}{l}\text { Major } \\
\text { depressive } \\
\text { disorder } \\
\text { (MDD) or } \\
\text { generalized } \\
\text { anxiety } \\
\text { disorder } \\
\text { (GAD) } \\
\text { [CIDI] }\end{array}$ & $\begin{array}{l}\text { The longitudinal association between } \\
\text { experiencing loneliness and higher } \\
\text { likelihood of suffering from GAD two } \\
\text { years later is bidirectional, whereas the } \\
\text { association between social isolation and } \\
\text { higher likelihood of subsequent MDD or } \\
\text { GAD as well as those between loneliness } \\
\text { and subsequent MDD or deterioration of } \\
\text { social integration are unidirectional. }\end{array}$ \\
\hline Evans et al., 2019 & $\begin{array}{l}\mathrm{n}=2135 \text { elderly } \\
\text { residents } \\
{[\text { Wales] }} \\
\text { Age: } \geq 65\end{array}$ & $\begin{array}{l}\text { Data from } \\
\text { the } \\
\text { Cognitive } \\
\text { Function and } \\
\text { Ageing } \\
\text { Study-Wales } \\
\text { (CFAS- } \\
\text { Wales) }\end{array}$ & $\begin{array}{l}2 \text { timepoints } \\
\text { T1: baseline } \\
\text { T2: 2-year } \\
\text { follow-up }\end{array}$ & LSNS-6 & $\begin{array}{l}\text { Depression } \\
\text { and anxiety } \\
\text { [AGECAT] }\end{array}$ & $\begin{array}{l}\text { Older people with depression or anxiety } \\
\text { perceived themselves as more isolated } \\
\text { than those without depression or anxiety, } \\
\text { despite having an equivalent level of } \\
\text { social contact with friends and family. In } \\
\text { people with depression or anxiety, social } \\
\text { isolation was associated with poor } \\
\text { cognitive function at baseline, but not with } \\
\text { cognitive change at 2-year follow-up. }\end{array}$ \\
\hline $\begin{array}{l}\text { Herbolsheimer et } \\
\text { al., } 2018\end{array}$ & $\begin{array}{l}\mathrm{n}=334 \\
\text { community- } \\
\text { dwelling older } \\
\text { adults } \\
\text { [Germany] } \\
\text { Age: } 65-84\end{array}$ & $\begin{array}{l}\text { Longitudinal } \\
\text { study }\end{array}$ & $\begin{array}{l}2 \text { timepoints } \\
\text { T1: baseline } \\
\text { T2: } 3 \text { years } \\
\text { later }\end{array}$ & LSNS-6 & $\begin{array}{l}\text { Depressive } \\
\text { symptoms } \\
\text { [HADS] }\end{array}$ & $\begin{array}{l}\text { Being socially isolated was associated } \\
\text { with lower levels of out-of-home physical } \\
\text { activity, and this predicted more } \\
\text { depressive symptoms after } 3 \text { years. } \\
\text { However, no direct relationship was } \\
\text { observed between social isolation from } \\
\text { friends and neighbors at the baseline and } \\
\text { depressive symptoms } 3 \text { years later. }\end{array}$ \\
\hline $\begin{array}{l}\text { Holvast et al., } \\
2015\end{array}$ & $\begin{array}{l}\mathrm{n}=285 \text { older } \\
\text { adults } \\
{[\text { Netherlands }]} \\
\text { Age: } \geq 60\end{array}$ & $\begin{array}{l}\text { Multi-site } \\
\text { prospective } \\
\text { cohort study } \\
\text { from the } \\
\text { Netherlands } \\
\text { Study of } \\
\text { Depression } \\
\text { in Older } \\
\text { Persons } \\
\text { (NESDO) }\end{array}$ & $\begin{array}{l}2 \text { timepoints } \\
\text { T1: baseline } \\
\text { T2: 2-year } \\
\text { follow-up }\end{array}$ & $\begin{array}{l}\text { De Jong } \\
\text { Gierveld } \\
\text { Loneliness } \\
\text { scale }\end{array}$ & $\begin{array}{l}\text { Depression } \\
\text { [CIDI] } \\
\text { Depression } \\
\text { severity } \\
\text { [IDS-SR] }\end{array}$ & $\begin{array}{l}\text { Loneliness, subjective appraisal of social } \\
\text { isolation, was a significant positive } \\
\text { determinant of depressive symptom } \\
\text { severity during follow-up. This association } \\
\text { was independent of social network size } \\
\text { and persisted after controlling for other } \\
\text { potential confounders. }\end{array}$ \\
\hline
\end{tabular}


Table 3. Characteristics of included studies on social network

\begin{tabular}{|c|c|c|c|c|c|c|}
\hline Reference & $\begin{array}{l}\text { Sample/Setting } \\
\text { [Country] }\end{array}$ & Study Type & $\begin{array}{l}\text { Follow-up } \\
\text { Times }\end{array}$ & $\begin{array}{l}\text { Social } \\
\text { Network } \\
\text { [Measure] }\end{array}$ & $\begin{array}{l}\text { MH } \\
\text { Outcome } \\
\text { [Measure] }\end{array}$ & Main Findings for Social Network \\
\hline $\begin{array}{l}\text { Chang et al., } \\
2016\end{array}$ & $\begin{array}{l}\mathrm{n}=21728 \\
\text { elderly women } \\
\text { [USA] } \\
\text { age: } \geq 65\end{array}$ & $\begin{array}{l}\text { Prospective } \\
\text { cohort study: } \\
\text { Nurses' Health } \\
\text { Study (NHS) }\end{array}$ & $\begin{array}{l}5 \text { timepoints, } \\
\text { Baseline and } 4 \\
\text { biennial } \\
\text { follow-up } \\
\text { questionnaire } \\
\text { cycles over } \\
10 \text {-year period }\end{array}$ & $\begin{array}{l}\text { Berkman- } \\
\text { Syme Social } \\
\text { Network } \\
\text { Index }\end{array}$ & $\begin{array}{l}\text { Depression } \\
\text { [MHI-5 } \\
\text { subscale of } \\
\text { the SF-36, } \\
\text { CESD-10, } \\
\text { GDS-15] }\end{array}$ & $\begin{array}{l}\text { Social factors (lower social network; lower } \\
\text { subjective social status; high caregiving } \\
\text { burden to disabled/ill relatives) were } \\
\text { associated with higher incident late-life } \\
\text { depression risk in age-adjusted models. }\end{array}$ \\
\hline $\begin{array}{l}\text { Domènech- } \\
\text { Abella et al., } \\
2019\end{array}$ & $\begin{array}{l}\mathrm{n}=5066 \text { adults } \\
\text { [Ireland] } \\
\text { age } \geq 50\end{array}$ & $\begin{array}{l}\text { Irish } \\
\text { Longitudinal } \\
\text { Study on } \\
\text { Ageing } \\
\text { (TILDA) }\end{array}$ & $\begin{array}{l}2 \text { waves of } \\
\text { TILDA } \\
\text { Second wave: } \\
2012-13 \\
\text { Third wave: } \\
\text { 2014-15 }\end{array}$ & $\begin{array}{l}\text { Berkman- } \\
\text { Syme Social } \\
\text { Network } \\
\text { Index }\end{array}$ & $\begin{array}{l}\text { MDD or } \\
\text { GAD } \\
\text { [CIDI] }\end{array}$ & $\begin{array}{l}\text { Both objective social isolation (size of } \\
\text { social network) and loneliness factors have } \\
\text { been found to be robust risk factors for } \\
\text { depression and anxiety independently, } \\
\text { which acts as a warning not to } \\
\text { underestimate the subjective aspects of } \\
\text { social isolation. }\end{array}$ \\
\hline $\begin{array}{l}\text { Förster et al., } \\
2018\end{array}$ & $\begin{array}{l}\mathrm{n}=783 \text { elderly } \\
\text { people } \\
{[\text { Germany }]} \\
\text { Age: } \geq 75\end{array}$ & $\begin{array}{l}\text { Population- } \\
\text { based cohort } \\
\text { study: Leipzig } \\
\text { Longitudinal } \\
\text { Study of the } \\
\text { Aged } \\
\text { (LEILA) }\end{array}$ & $\begin{array}{l}3 \text { timepoints } \\
\text { T1: baseline } \\
\text { T2: follow- } \\
\text { up1 } \\
\text { T3: follow- } \\
\text { up2 }\end{array}$ & PANT & $\begin{array}{l}\text { Depressive } \\
\text { symptoms } \\
\text { [CES-D] }\end{array}$ & $\begin{array}{l}\text { Persons with a restricted social network } \\
\text { were more likely to develop depression. } \\
\text { Risk of depression was particularly high for } \\
\text { elderly with social loss experiences. An } \\
\text { integrated social network may buffer the } \\
\text { negative effects of loss on depression. }\end{array}$ \\
\hline $\begin{array}{l}\text { Noteboom et } \\
\text { al., } 2016\end{array}$ & $\begin{array}{l}\mathrm{n}=1085 \\
\text { respondents } \\
\text { from health } \\
\text { care settings } \\
\text { [Netherlands] } \\
\text { Age: }>18\end{array}$ & $\begin{array}{l}\text { Longitudinal } \\
\text { cohort study: } \\
\text { Netherlands } \\
\text { Study of } \\
\text { Depression } \\
\text { and Anxiety } \\
\text { (NESDA) }\end{array}$ & $\begin{array}{l}2 \text { timepoints } \\
\text { T1: baseline } \\
\text { T2: 2-year } \\
\text { follow-up }\end{array}$ & $\begin{array}{l}\text { Questions on } \\
\text { how many } \\
\text { relatives, } \\
\text { friends or } \\
\text { others over the } \\
\text { age of } 18 \\
\text { years they had } \\
\text { regular and } \\
\text { important } \\
\text { contact }\end{array}$ & $\begin{array}{l}\text { Depressive } \\
\text { disorders } \\
\text { [CIDI] }\end{array}$ & $\begin{array}{l}\text { Structural (network size and partner status) } \\
\text { did not predict depression at follow up. The } \\
\text { group with a lifetime history of depression } \\
\text { reported a smaller social network. }\end{array}$ \\
\hline $\begin{array}{l}\text { Van Den Brink } \\
\text { et al., } 2018\end{array}$ & $\begin{array}{l}\mathrm{n}=1474 \text { patients } \\
\text { with a major } \\
\text { depressive } \\
\text { disorder } \\
\text { [Netherlands] } \\
\text { Age: } 18-90\end{array}$ & $\begin{array}{l}\text { Data from } 2 \\
\text { cohort studies } \\
\text { NESDA and } \\
\text { Netherlands } \\
\text { Study of } \\
\text { Depression in } \\
\text { Older Persons } \\
\text { (NESDO) }\end{array}$ & & $\begin{array}{l}\text { Questions on } \\
\text { social network } \\
\text { characteristics }\end{array}$ & $\begin{array}{l}\text { Presence of } \\
\text { depression } \\
\text { [CIDI] } \\
\text { Depression } \\
\text { severity } \\
\text { [IDS-SR] }\end{array}$ & $\begin{array}{l}\text { Social network characteristics, such as } \\
\text { having a partner and number of persons in } \\
\text { one's household, are related to depression } \\
\text { course. }\end{array}$ \\
\hline $\begin{array}{l}\text { Reynolds et al., } \\
2020\end{array}$ & $\begin{array}{l}\mathrm{N}=3005 \text { elderly } \\
\text { people } \\
\text { [USA] } \\
\text { Age: } 57-85\end{array}$ & $\begin{array}{l}\text { Panel data } \\
\text { from National } \\
\text { Social Life, } \\
\text { Health, and } \\
\text { Aging Project } \\
\text { (NSHAP) }\end{array}$ & $\begin{array}{l}3 \text { waves } \\
2005,2010, \\
\text { and } 2015 \text { with } \\
\text { 5-year } \\
\text { intervals } \\
\text { between each } \\
\text { wave }\end{array}$ & $\begin{array}{l}\text { Questions on } \\
\text { community- } \\
\text { layer, } \\
\text { interpersonal- } \\
\text { layer, and } \\
\text { partner-layer } \\
\text { connection }\end{array}$ & $\begin{array}{l}\text { Depressive } \\
\text { symptoms } \\
\text { [CES-D] }\end{array}$ & $\begin{array}{l}\text { Results demonstrate multiple links between } \\
\text { social connection and depression, and that } \\
\text { the evolution of social networks in older } \\
\text { adults is complex, with distinct mechanisms } \\
\text { leading to positive and negative outcomes. } \\
\text { Specifically, community involvement } \\
\text { showed consistent benefits in reducing } \\
\text { depression. }\end{array}$ \\
\hline $\begin{array}{l}\text { Santini et al., } \\
2020\end{array}$ & & & & $\begin{array}{l}\text { Social } \\
\text { Disconnectedn } \\
\text { ess Scale }\end{array}$ & $\begin{array}{l}\text { Depressive } \\
\text { symptoms } \\
\text { [CES-D- } \\
\text { ML] } \\
\text { Anxiety } \\
\text { [HADS-A] }\end{array}$ & $\begin{array}{l}\text { No evidence that social disconnectedness } \\
\text { (ie, having a small network or infrequent } \\
\text { social interaction) predicted higher } \\
\text { frequencies of depression symptoms at } \\
\text { subsequent timepoints }(\beta=0 \cdot 003 ; \mathrm{p}=0 \cdot 77 ; \\
\text { data not shown) was found. Social } \\
\text { disconnectedness predicted higher amounts } \\
\text { of perceived isolation, which in turn } \\
\text { predicted higher amounts of depression and } \\
\text { anxiety symptoms. }\end{array}$ \\
\hline \multicolumn{7}{|c|}{$\begin{array}{l}\text { Checklist: CES-D = Center for Epidemiological Studies-Depression Scale; CES-D-ML = Center for Epidemiological Studies-Depression Minus } \\
\text { Loneliness Scale; CIDI = Composite International Diagnostic Interview; GAD = Generalized Anxiety Disorder; GDS = Geriatric Depression Scale; } \\
\text { HADS = Hospital Anxiety and Depression Scale; IDS-SR = Inventory of Depressive Symptomatology Self-Report version; MDD = Major Depressive } \\
\text { Disorder; MHI-5 = Mental Health Index-5 }\end{array}$} \\
\hline
\end{tabular}




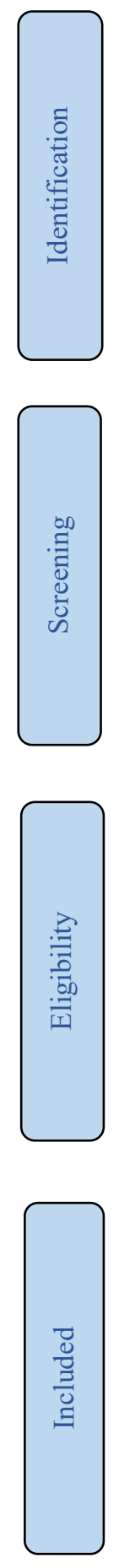

Records identified though database screening PubMed: 8497; PsychInfo: 7300

$$
(\mathrm{n}=15497)
$$

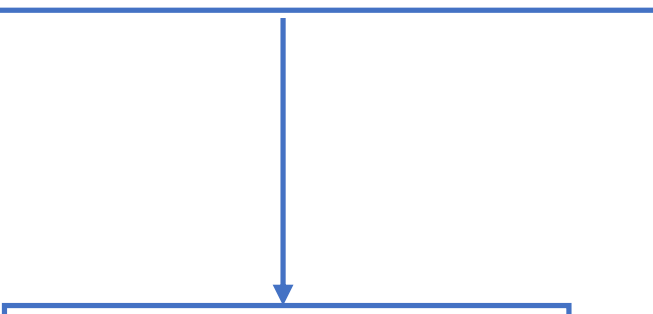

Records after duplicates removed

Titles/Abstracts screened

$$
(\mathrm{n}=6532)
$$

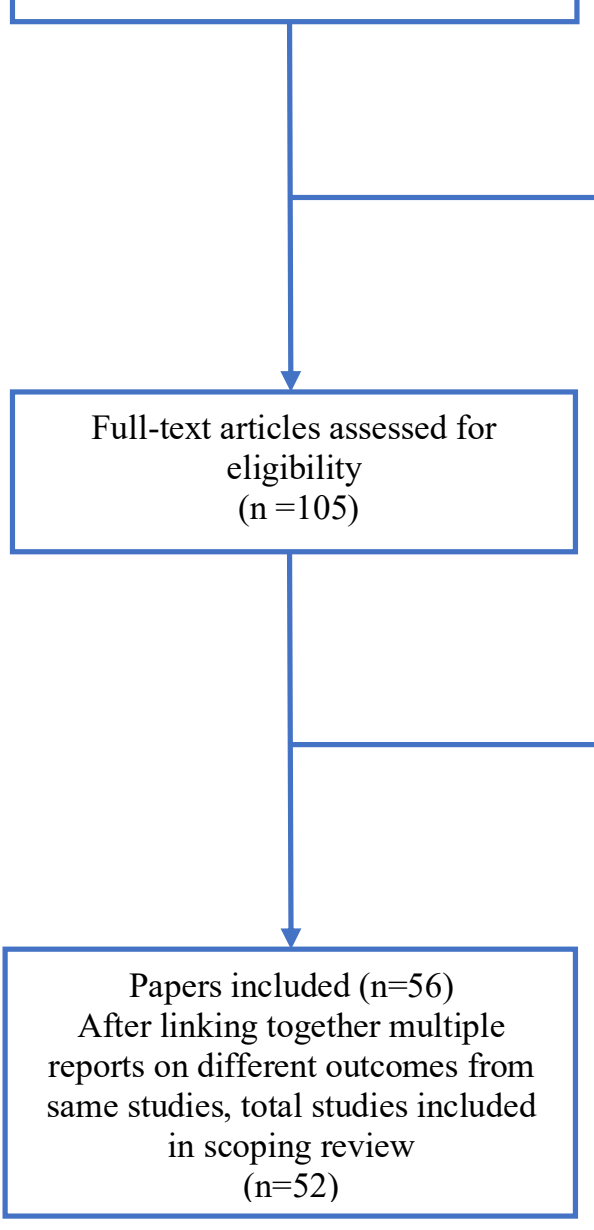

\section{Records excluded} $(\mathrm{n}=6431)$

Methodology $(\mathrm{n}=2144)$

Topic $(n=3160)$

Study population $(\mathrm{n}=1127)$

Lit search strategy: ((("social* support *"or "social* isolation*" or "social *network *") AND (Depression OR Anxiety)) AND (("2015/1/1"[Date - Publication]: "2020/12/31"[Date - Publication]))) AND (English [Language])

Fig 1. PRISMA flow chart of the scoping review. PRISMA diagram showing search and selection process of scoping review. 


\section{Preferred Reporting Items for Systematic reviews and Meta-Analyses extension for Scoping Reviews (PRISMA-ScR) Checklist}

\begin{tabular}{|c|c|c|c|}
\hline SECTION & ITEM & PRISMA-ScR CHECKLIST ITEM & REPORTED ON PAGE \# \\
\hline \multicolumn{4}{|l|}{ TITLE } \\
\hline Title & 1 & Identify the report as a scoping review. & 1 \\
\hline \multicolumn{4}{|l|}{ ABSTRACT } \\
\hline $\begin{array}{l}\text { Structured } \\
\text { summary }\end{array}$ & 2 & $\begin{array}{l}\text { Provide a structured summary that } \\
\text { includes (as applicable): background, } \\
\text { objectives, eligibility criteria, sources of } \\
\text { evidence, charting methods, results, } \\
\text { and conclusions that relate to the review } \\
\text { questions and objectives. }\end{array}$ & 2 \\
\hline \multicolumn{4}{|l|}{ INTRODUCTION } \\
\hline Rationale & 3 & $\begin{array}{l}\text { Describe the rationale for the review in } \\
\text { the context of what is already known. } \\
\text { Explain why the review } \\
\text { questions/objectives lend themselves to } \\
\text { a scoping review approach. }\end{array}$ & 3 \\
\hline Objectives & 4 & $\begin{array}{l}\text { Provide an explicit statement of the } \\
\text { questions and objectives being } \\
\text { addressed with reference to their key } \\
\text { elements (e.g., population or } \\
\text { participants, concepts, and context) or } \\
\text { other relevant key elements used to } \\
\text { conceptualize the review questions } \\
\text { and/or objectives. }\end{array}$ & 3 \\
\hline \multicolumn{4}{|l|}{ METHODS } \\
\hline $\begin{array}{l}\text { Protocol and } \\
\text { registration }\end{array}$ & 5 & $\begin{array}{l}\text { Indicate whether a review protocol } \\
\text { exists; state if and where it can be } \\
\text { accessed (e.g., a Web address); and if } \\
\text { available, provide registration } \\
\text { information, including the registration } \\
\text { number. }\end{array}$ & $\mathrm{N} / \mathrm{A}$ \\
\hline Eligibility criteria & 6 & $\begin{array}{l}\text { Specify characteristics of the sources of } \\
\text { evidence used as eligibility criteria (e.g., } \\
\text { years considered, language, and } \\
\text { publication status), and provide a } \\
\text { rationale. }\end{array}$ & 4 \\
\hline $\begin{array}{l}\text { Information } \\
\text { sources* }^{*}\end{array}$ & 7 & $\begin{array}{l}\text { Describe all information sources in the } \\
\text { search (e.g., databases with dates of } \\
\text { coverage and contact with authors to } \\
\text { identify additional sources), as well as } \\
\text { the date the most recent search was } \\
\text { executed. }\end{array}$ & 4 \\
\hline Search & 8 & $\begin{array}{l}\text { Present the full electronic search } \\
\text { strategy for at least } 1 \text { database, } \\
\text { including any limits used, such that it } \\
\text { could be repeated. }\end{array}$ & 4 \\
\hline $\begin{array}{l}\text { Selection of } \\
\text { sources of } \\
\text { evidence† }\end{array}$ & 9 & $\begin{array}{l}\text { State the process for selecting sources } \\
\text { of evidence (i.e., screening and } \\
\text { eligibility) included in the scoping } \\
\text { review. }\end{array}$ & 4 \\
\hline $\begin{array}{l}\text { Data charting } \\
\text { process }\end{array}$ & 10 & $\begin{array}{l}\text { Describe the methods of charting data } \\
\text { from the included sources of evidence }\end{array}$ & $4-5$ \\
\hline
\end{tabular}




\begin{tabular}{|c|c|c|c|}
\hline SECTION & ITEM & PRISMA-ScR CHECKLIST ITEM & REPORTED ON PAGE \# \\
\hline & & $\begin{array}{l}\text { (e.g., calibrated forms or forms that } \\
\text { have been tested by the team before } \\
\text { their use, and whether data charting } \\
\text { was done independently or in duplicate) } \\
\text { and any processes for obtaining and } \\
\text { confirming data from investigators. }\end{array}$ & \\
\hline Data items & 11 & $\begin{array}{l}\text { List and define all variables for which } \\
\text { data were sought and any assumptions } \\
\text { and simplifications made. }\end{array}$ & $4-5$ \\
\hline $\begin{array}{l}\text { Critical appraisal } \\
\text { of individual } \\
\text { sources of } \\
\text { evidence }\end{array}$ & 12 & $\begin{array}{l}\text { If done, provide a rationale for } \\
\text { conducting a critical appraisal of } \\
\text { included sources of evidence; describe } \\
\text { the methods used and how this } \\
\text { information was used in any data } \\
\text { synthesis (if appropriate). }\end{array}$ & $\mathrm{N} / \mathrm{A}$ \\
\hline $\begin{array}{l}\text { Synthesis of } \\
\text { results }\end{array}$ & 13 & $\begin{array}{l}\text { Describe the methods of handling and } \\
\text { summarizing the data that were charted. }\end{array}$ & 5 \\
\hline \multicolumn{4}{|l|}{ RESULTS } \\
\hline $\begin{array}{l}\text { Selection of } \\
\text { sources of } \\
\text { evidence }\end{array}$ & 14 & $\begin{array}{l}\text { Give numbers of sources of evidence } \\
\text { screened, assessed for eligibility, and } \\
\text { included in the review, with reasons for } \\
\text { exclusions at each stage, ideally using a } \\
\text { flow diagram. }\end{array}$ & 5 \& Fig1 \\
\hline $\begin{array}{l}\text { Characteristics of } \\
\text { sources of } \\
\text { evidence }\end{array}$ & 15 & $\begin{array}{l}\text { For each source of evidence, present } \\
\text { characteristics for which data were } \\
\text { charted and provide the citations. }\end{array}$ & $5-13$ \\
\hline $\begin{array}{l}\text { Critical appraisal } \\
\text { within sources of } \\
\text { evidence }\end{array}$ & 16 & $\begin{array}{l}\text { If done, present data on critical } \\
\text { appraisal of included sources of } \\
\text { evidence (see item 12). }\end{array}$ & $\mathrm{N} / \mathrm{A}$ \\
\hline $\begin{array}{l}\text { Results of } \\
\text { individual } \\
\text { sources of } \\
\text { evidence }\end{array}$ & 17 & $\begin{array}{l}\text { For each included source of evidence, } \\
\text { present the relevant data that were } \\
\text { charted that relate to the review } \\
\text { questions and objectives. }\end{array}$ & $5-13$ \\
\hline $\begin{array}{l}\text { Synthesis of } \\
\text { results }\end{array}$ & 18 & $\begin{array}{l}\text { Summarize and/or present the charting } \\
\text { results as they relate to the review } \\
\text { questions and objectives. }\end{array}$ & $5-13$ \\
\hline \multicolumn{4}{|l|}{ DISCUSSION } \\
\hline $\begin{array}{l}\text { Summary of } \\
\text { evidence }\end{array}$ & 19 & $\begin{array}{l}\text { Summarize the main results (including } \\
\text { an overview of concepts, themes, and } \\
\text { types of evidence available), link to the } \\
\text { review questions and objectives, and } \\
\text { consider the relevance to key groups. }\end{array}$ & $13-14$ \\
\hline Limitations & 20 & $\begin{array}{l}\text { Discuss the limitations of the scoping } \\
\text { review process. }\end{array}$ & 15 \\
\hline Conclusions & 21 & $\begin{array}{l}\text { Provide a general interpretation of the } \\
\text { results with respect to the review } \\
\text { questions and objectives, as well as } \\
\text { potential implications and/or next steps. }\end{array}$ & $15-16$ \\
\hline \multicolumn{4}{|l|}{ FUNDING } \\
\hline Funding & 22 & $\begin{array}{l}\text { Describe sources of funding for the } \\
\text { included sources of evidence, as well as } \\
\text { sources of funding for the scoping } \\
\text { review. Describe the role of the funders } \\
\text { of the scoping review. }\end{array}$ & $\begin{array}{l}\text { We did not include funding } \\
\text { sources in the Acknowledgments } \\
\text { or anywhere else in the } \\
\text { manuscript file as is stated in the } \\
\text { guidelines. Funding information }\end{array}$ \\
\hline
\end{tabular}


$\mathrm{JBI}=$ Joanna Briggs Institute; PRISMA-ScR = Preferred Reporting Items for Systematic reviews and Meta-Analyses extension for Scoping Reviews.

* Where sources of evidence (see second footnote) are compiled from, such as bibliographic databases, social media platforms, and Web sites.

† A more inclusive/heterogeneous term used to account for the different types of evidence or data sources (e.g., quantitative and/or qualitative research, expert opinion, and policy documents) that may be eligible in a scoping review as opposed to only studies. This is not to be confused with information sources (see first footnote). ¥ The frameworks by Arksey and O'Malley $(6)$ and Levac and colleagues $(7)$ and the JBI guidance $(4,5)$ refer to the process of data extraction in a scoping review as data charting.

$\S$ The process of systematically examining research evidence to assess its validity, results, and relevance before using it to inform a decision. This term is used for items 12 and 19 instead of "risk of bias" (which is more applicable to systematic reviews of interventions) to include and acknowledge the various sources of evidence that may be used in a scoping review (e.g., quantitative and/or qualitative research, expert opinion, and policy document).

From: Tricco AC, Lillie E, Zarin W, O'Brien KK, Colquhoun H, Levac D, et al. PRISMA Extension for Scoping Reviews (PRISMAScR): Checklist and Explanation. Ann Intern Med. ;169:467-473. doi: 10.7326/M18-0850 